\title{
A lei da regularização fundiária (Lei 13.465/2017): análise inicial de suas principais repercussões para o direito de propriedade
}

\author{
The urban land regularization law (Law 13.465/2017): initial analysis of its main \\ repercussions into property law
}

Flávio Tartuce*

\section{Resumo}

\begin{abstract}
Este artigo científico pretende analisar e trazer as primeiras reflexões sobre a Lei 13.465/2017, norma jurídica de grande importância que promoveu amplas modificações no sistema de propriedades no Brasil, tratando da Regularização Fundiária Urbana (REURB). Neste texto, serão abordados apenas alguns temas, como a visão geral dessa política, o instituto da legitimação fundiária, as novas modalidades de condomínio e o direito real de laje. Fez-se um estudo crítico dessas categorias, que apresentam novos desafios não só para o Direito Civil, como também para outros ramos jurídicos, como o Direito Administrativo, o Direito Constitucional, o Direito Urbanístico e o Direito Notarial e Registral.
\end{abstract}

Palavras-chave: Direito civil. Direito das coisas. Propriedade. Lei da Regularização Fundiária Urbana.

\section{Abstract}

This scientific article intends to analyze and bring the first reflections on Law 13.465/2017, a legal norm of great importance that promoted wide modifications in property in Brazil, dealing with Urban Land Regularization (REURB). In this text, only a few topics will be raised, such as the general view of this policy, the land legalization institute, the new condominium modalities and the property right of "laje". A critical study will be made over the categories, which present new challenges not only for Civil Law, but also for other legal branches, such as Administrative Law, Constitutional Law, Urban Law, Notarial and Registral Law.

Keywords: Civil law. Property law. Property. Urban Land Regularization Law.

\section{Introdução}

A propriedade é um dos institutos mais controversos do Direito, especialmente no âmbito do Direito Privado. A controvérsia começa no seu próprio conceito, segue na análise de sua natureza jurídica e dos seus atributos, e chega na compreensão do que seja a função social da propriedade, conceito constante da grande maioria das Constituições e codificações do sistema da Civil Law.

Sobre o conceito de propriedade, a propósito, poucas leis procuraram trazê-lo, diante das enormes dificuldades em seu preenchimento. Diante da falta de positivação no Direito Brasileiro, sempre chamou atenção a definição constante do art. 2.167 do antigo Código Civil Português - o Código Seabra -, segundo a qual: "Diz-se direito de propriedade a faculdade que o homem tem, de aplicar à conservação da sua existência, e ao melhoramento da sua condição, tudo quanto para esse fim legitimidade adquiriu, e de que, portanto, pode dispor livremente". Apesar de ser um conceito passível de muitas críticas, sobretudo pelo apego individualista e servil ao homem, a construção traz uma boa ideia sobre a propriedade, algo que acompanha a pessoa desde o início de sua existência até o final dos seus dias.

Doutor em Direito Civil pela USP. Mestre em Direito Civil Comparado pela PUC-SP. Professor Titular permanente do programa de mestrado e doutorado da FADISP. Professor e coordenador dos cursos de pós-graduação lato sensu da EPD. Advogado em São Paulo, parecerista e consultor jurídico. São Paulo-SP-Brasil. E-mail: fftartuce@uol.com.br. 
No Brasil, como também em outros lugares do mundo, a propriedade sempre foi foco de tensões, com a colisão de visões contrapostas de mundo, como afirma Paulo Lôbo (2015, p. 95). Nas suas palavras, "a propriedade é o grande foco de tensão entre as correntes individualistas e solidaristas. O direito de propriedade, no Estado democrático e social de direito, como o da Constituição brasileira de 1988, termina por refletir esse conflito". No caso brasileiro, o problema relativo à distribuição das propriedades remonta à sua formação inicial, sobretudo diante do sistema clientelista das sesmarias e do caos dominial que surgiu após a sua extinção, não resolvido pela tão criticada Lei de Terras (Lei 601/1850). ${ }^{1}$

Quanto à distribuição da propriedade urbana, os problemas que ocorreram no campo acabaram se repetindo nas cidades, fazendo eclodir, na grande maioria dos Municípios brasileiros, habitações em situações precárias, especialmente em favelas, hoje denominadas comunidades. Diante dessa realidade, nos últimos anos, surgiu uma preocupação do legislador em buscar uma regularização possível dessas áreas, por institutos jurídicos diversos. Almeja-se retirar tais situações dominiais de um "underground jurídico" ou, como afirmam os italianos, do il Torto para o il Diritto.

Uma das primeiras tentativas se deu com o Decreto-lei 271/1967, que tratou da concessão real de uso nos seus arts. $7^{\circ}$ e $8^{\circ}$, com as alterações posteriores que foram feitas por meio da Lei 11.481/2007. Conforme o primeiro dispositivo, é instituída a concessão de uso de terrenos públicos ou particulares, remunerada ou gratuita, por tempo determinado ou indeterminado, como direito real resolúvel, para fins específicos de regularização fundiária de interesse social, urbanização, industrialização, edificação, cultivo da terra, aproveitamento sustentável das várzeas, preservação das comunidades tradicionais e de seus meios de subsistência ou outras modalidades de interesse social em áreas urbanas. Apesar desse tratamento até remoto no tempo, infelizmente, o instituto em questão não foi devidamente concretizado na realidade dominial brasileira.

Também merece destaque a Medida Provisória 2.220/2001 - incrivelmente, ainda em tramitação -, que regula a concessão de uso para fins de moradia. Nos termos do seu art. $1^{\circ}$, ora modificado pela Lei 13.465/2017,

Aquele que, até 22 de dezembro de 2016, possuir como seu, por cinco anos, ininterruptamente e sem oposição, até duzentos e cinquenta metros quadrados de imóvel público situado em área urbana, utilizando-o para sua moradia ou de sua família, tem o direito à concessão de uso especial para fins de moradia em relação ao bem objeto da posse, desde que não seja proprietário ou concessionário, a qualquer título, de outro imóvel urbano ou rural.

Anote-se que a norma de 2017 alterou o teor do comando ao mencionar um novo lapso temporal, com o fim de ampliar a extensão do direito real, que também não foi efetivado como se esperava. A regra anterior previa a data de 30 de junho de 2001, quando surgiu a Medida Provisória.

Em relação a essas duas concessões especiais, sabe-se que a Lei 11.481/2007 introduziu-as como direitos reais de gozo ou fruição no art. 1.225 do Código Civil (incs. XI e XII), mais uma vez com o objetivo de sua efetiva aplicação, o que novamente não ocorreu para a regularização de áreas favelizadas.

Outro instituto que surgiu com esse fim foi a legitimação da posse urbana, tratada pela Lei 11.977/2009, conhecida como Lei Minha Casa, Minha Vida. Conforme o seu art. 59, a legitimação da posse, devidamente registrada no Cartório de Registro de Imóveis, constituiria direito em favor do detentor da posse direta para fins de moradia. Reconhecido o instituto como um direito real, como realmente parecia ser, verificava-se que ele ampliava o rol do art. 1.225 do CC/2002. Não se olvide que a legitimação da posse já era tratada com relevo no âmbito do Direito Agrário, tendo sido criada pela Lei de Terras e regulamentada pela Lei

\footnotetext{
A propósito, como pontua Marco Aurélio Bezerra de Melo (2008, p. 29-30), Desembargador do Tribunal de Justiça do Rio de Janeiro, em sua dissertação de mestrado, "o advento da lei de terras deixou marcas profundas na história brasileira, levando a travessia do país do feudalismo ao capitalismo, com a substituição do regime escravocrata pelo assalariado, tornando a terra mercadoria e constituindo uma nova classe social a quem é extremamente difícil chegar, no campo ou na cidade, ao sonho burguês da propriedade formal: os trabalhadores assalariados. Tivessem os objetivos da lei de funcionalidade da propriedade imóvel preponderado haveria, por conseguinte, distribuição equitativa do território brasileiro, mas como já referimos anteriormente, aludindo a Raymundo Faoro, a malícia dos fatos acabou nos afastando de uma justiça no campo e, posteriormente, nas cidades.".
} 
6.383/1976 (art. 29), havendo corrente doutrinária substanciosa, entre os agraristas, afirmando tratar-se de um direito real. ${ }^{2}$

Pois bem, com claro intuito político de suplementação do tratamento anterior, os dispositivos da Lei Minha Casa, Minha Vida que tratavam da categoria foram revogados pela Lei 13.465/2017, que procurou afastar vários dos seus institutos, substituindo a política dominial anterior por outra, especialmente pela Regularização Fundiária Urbana (REURB). A legitimação da posse passou a ser tratada de outra forma, sendo definida pelo art. 11, inciso $\mathrm{VI}$, da novel legislação como o ato do poder público destinado a conferir título, por meio do qual fica reconhecida a posse de imóvel objeto da REURB, conversível em aquisição de direito real de propriedade na forma, com a identificação de seus ocupantes, do tempo da ocupação e da natureza da posse. A conversão em propriedade continua a ser efetivada por meio de usucapião administrativa, como ainda se verá neste trabalho.

Em complemento, conforme o art. 25 da Lei 13.465/2017, a legitimação de posse, instrumento de uso exclusivo para fins de regularização fundiária, constitui ato do poder público destinado a conferir título, por meio do qual fica reconhecida a posse de imóvel objeto da REURB, com a identificação de seus ocupantes, do tempo da ocupação e da natureza da posse, que é conversível em direito real de propriedade, na forma da própria norma em estudo. Nota-se que não há mais previsão de que a legitimação de posse cria direito ao possuidor, como estava na Lei 11.977/2009, mas apenas confere título, podendo ser afastada a tese de que se trata de um direito real. Todavia, diante da posição doutrinária de que a legitimação de posse agrária é um direito real, a afirmação anterior, relativa à legitimação da posse urbana, pode ser mantida, na opinião deste autor.

Penso que essas tentativas atuais de regularização das favelas no Brasil pecam por três problemas fundamentais. O primeiro deles é a carência de efetivação, notadamente de políticas públicas eficientes. O segundo problema é a instabilidade legislativa, merecendo destaque o que ocorreu com a recente Lei 11.977/2009. O terceiro é a falta de cuidado técnico do legislador recente no tratamento das categorias jurídicas consolidadas pelo Direito Civil.

Será que a Lei 13.465/2017 conseguirá superar esses problemas e atingir os seus objetivos, regularizando os imóveis que se encontram em situação de informalidade, notadamente nas comunidades? Acertou o legislador ao consagrar novas categorias e ao tratar de maneira diferente outras que já eram admitidas pelo nosso Direito? O presente artigo procurará responder a tais questões, em alguns aspectos da nova legislação, com impacto importante e direto para institutos reais.

\section{Panorama geral da Lei 13.465/2017. O pedido de reconhecimento de sua inconstitucionalidade pelo Ministério Público Federal}

Como destacado na introdução deste estudo, a recente Lei 13.465, de 11 de julho de 2017, trouxe mudanças importantes para os institutos reais, relacionados à propriedade plena ou limitada. Em resumo, podemos destacar como suas principais inovações ou modificações: a) introdução do direito real de laje no rol do art. 1.225 do Código Civil; b) regulamentação do direito real de laje entre os arts. 1.510-A a 1.510-E da codificação material e também na Lei de Registros Públicos (Lei 6.015/1973); c) alteração dos requisitos para a usucapião urbana coletiva, tratada pelo Estatuto da Cidade; $d$ ) modificações no tratamento da usucapião extrajudicial ou administrativa, tornando-a possível juridicamente e sanando algumas dúvidas (alterações no art. 216-A da Lei de Registros Públicos, incluído pelo CPC/2015); e) introdução de novas modalidades de condomínio: o condomínio de lotes e o condomínio urbano simples; f) regulamentação

\footnotetext{
Nessa perspectiva, leciona Benedito Ferreira Marques (2011, p. 87) que "tem-se que se trata de instituto tipicamente brasileiro, cujos fundamentos jurídicos têm merecido, até aqui, a mais acurada análise dos estudiosos, posto que, a partir de sua criação, vem atravessando os tempos, chegando a merecer guarida nos próprios textos constitucionais republicanos e na legislação margeante. O seu conceito decorre do próprio dispositivo que o concebeu e consagrou, por isso que L. Lima Stefanini assim a definiu: 'é a exaração de ato administrativo, através do qual o Poder Público reconhece ao particular que trabalhava na terra a sua condição de legitimidade, outorgando, ipso facto, o formal domínio pleno'”. O jurista apresenta, nesse trecho da obra, posicionamento liderado por Getúlio Targino Lima entre os agraristas, no sentido de tratar-se de um direito real.
} 
do sistema de arrecadação de bens vagos, para os casos de abandono (o art. 1.276 do Código Civil); g) revogação de todo o capítulo da Lei Minha Casa, Minha Vida (Lei 11.977/2009) relativo à regularização fundiária, alterando substancialmente a legitimação da posse e a usucapião extrajudicial dela decorrente; h) alterações de procedimentos relativos à alienação fiduciária em garantia de bens imóveis, facilitando o recebimento dos créditos; i) modificações na Medida Provisória 2.220, que trata da concessão especial de uso; j) alterações da Lei 9.636/1998, que trata da alienação de bens imóveis da União, facilitando a extinção da enfiteuse sobre terras da Marinha, por meio da remição; $k$ ) introdução de políticas para Regularização Fundiária Urbana (REURB); e l) introdução do instituto da legitimação fundiária.

Como se pode perceber, estão listadas doze mudanças fundamentais, sendo certo que aqui abordaremos apenas algumas delas, pela extensão e amplitude deste artigo científico. Antes dessa abordagem pontual, cabe destacar que a Lei 13.465/2017 tem origem na Medida Provisória 759, de dezembro de 2016, representando uma conversão desta e tendo ambas, como conteúdo principal, a regularização fundiária urbana e agrária. A norma emergente visa, como exposto, resolver os graves problemas de distribuição da terra e do domínio que acometem o Brasil desde os primórdios de sua ocupação, após o seu "descobrimento" por Portugal.

De todo modo, nota-se que a nova lei ampliou muito o conteúdo da sua Medida Provisória embrionária, o que motivou, entre outras razões, o ingresso de ação direta de inconstitucionalidade, por parte do Ministério Público Federal, no início de setembro de 2017 (ADI 5771). Argumenta o MPF, de início, que "61 entidades ligadas à defesa do ambiente convencidas de que a Lei 13.465/2017 causa ampla privatização de terras públicas, florestas, águas e ilhas federais na Amazônia e na zona costeira do Brasil", solicitaram o ingresso da demanda.

Sustenta ainda que não havia urgência para a edição da Medida Provisória 759, eivada de vício formal na origem, uma vez que "os vastos e graves problemas de terras no Brasil remontam ao período colonial, com a implantação do regime de sesmarias", pois "a grilagem de terras e desmatamento atravessaram séculos até aqui, literalmente, sem soluções de todo satisfatórias", não sendo "concebível que, de um momento para o outro, se transformem em problemas de tamanha urgência que demandem uso do instrumento excepcional e urgente que é a medida provisória, com usurpação da função legislativa ordinária do Congresso Nacional" (petição inicial da ADI 5771).

Para o Ministério Público Federal, igualmente, não haveria urgência no tratamento da regularização fundiária urbana, porque "também há problema estrutural, vivenciado há décadas país afora, e, por isso, incapaz de configurar urgência". É feita também uma crítica ao fato de terem sido revogadas as regras de regularização previstas na Lei 11.977/2009, pois os Municípios, já adaptados à realidade da Lei Minha Casa, Minha Vida, teriam que se readequar ao novo sistema, causando numerosas dúvidas e incertezas práticas.

A petição inicial proposta também traz como conteúdo o fundamento de que a Medida Provisória não poderia tratar de matéria reservada à lei complementar, eis que revogou os arts. 14 e 15 da Lei Complementar 76/1993, tratando do procedimento de rito sumário na desapropriação agrária. Haveria também vício formal pelo fato de ter alterado inúmeras normas importantes, como as Leis 8.629/1993 e 13.001/2014 (sobre reforma agrária), a Lei 8.666/1993 (sobre licitações), a Lei 11.952/2009 (que trata da chamada Amazônia Legal), a Lei 12.512/2011 (que trata do programa de apoio à conservação ambiental e o programa de fomento às atividades produtivas rurais), a Lei 6.015/1973 (Registros Públicos) e a Lei 11.977/2009 (Minha Casa, Minha Vida), entre outras. Mais uma vez, não haveria atendimento à essência do instituto pela Medida Provisória "para alterar mais de uma dezena de leis aprovadas pelo parlamento, algumas delas com mais de uma década de vigência ou até com mais de quarenta anos de existência" (ADI 5771).

Por fim, alegando que o fato de uma Medida Provisória ser convertida em lei não convalida seus vícios formais, conforme a jurisprudência do Supremo Tribunal Federal, o Ministério Público Federal pontua, na petição inicial da ADI 5771, que

não é necessário analisar de forma destacada cada dispositivo da Lei 13.465/2017, porque, fundamentalmente, ela fere a Constituição ao tratar de seus temas centrais - regularização fundiária rural, regularização fundiária urbana e desmatamento - em descompasso com numerosas diretrizes que a ordem constitucional estipula (petição inicial da ADI 5771). 
Sem dúvidas, a norma emergente parece apresentar alguns dos problemas citados, notadamente o fato de não haver urgência na Medida Provisória de origem. Em complemento, notamos que muitos dos seus temas, com exceção, por exemplo, do tratamento da laje, não foram devidamente debatidos perante a sociedade brasileira, pegando muitos de surpresa.

De toda sorte, apesar das minhas resistências pessoais à nova lei, que parece de fato estar eivada de graves vícios, e até de inconstitucionalidade, como quer o Ministério Público Federal, vejamos os pontos separados para este estudo atinentes ao direito de propriedade.

\section{Visão geral sobre a regularização fundiária urbana (REURB)}

A Lei 13.465/2017 instituiu mecanismos visando à Regularização Fundiária Urbana (REURB), para uma melhor distribuição das propriedades nas cidades. Também foram incluídas ferramentas para a Regularização Fundiária Rural, que não serão analisadas neste trabalho. Quanto à REURB, estabelece o art. $9^{\circ}$ da nova norma que ficam instituídas no território nacional normas gerais e procedimentos aplicáveis a essa forma de regularização, que abrange medidas jurídicas, urbanísticas, ambientais e sociais, destinadas à incorporação dos núcleos urbanos informais ao ordenamento territorial urbano e à titulação de seus ocupantes. Um dos objetivos da nova política, como se percebe, é justamente de regularização de áreas favelizadas, conclusão claramente retirada da leitura desse comando.

Nesse contexto de efetivação da função social da propriedade e da posse urbana, os poderes públicos formularão e desenvolverão no espaço urbano as políticas de suas competências de acordo com os princípios de sustentabilidade econômica, social e ambiental e ordenação territorial, buscando a ocupação do solo de maneira eficiente, combinando seu uso de forma funcional (art. $9^{\circ}$, $\S 1^{\circ}$, da Lei 13.465/2017). A Regularização Fundiária Urbana promovida mediante a legitimação fundiária, categoria nova que ainda será aqui estudada, somente poderá ser aplicada para os núcleos urbanos informais comprovadamente existentes até 22 de dezembro de 2016 (art. $9^{\circ}$, § $1^{\circ}$, da Lei 13.465/2017). Não incide, portanto, a legitimação fundiária para os núcleos informais que surgirem depois da emergência da nova legislação.

Nos termos do art. 10 da nova norma, são objetivos da REURB que devem ser observados por todas as esferas do Estado: a) identificar os núcleos urbanos informais que devam ser regularizados, organizálos e assegurar a prestação de serviços públicos aos seus ocupantes, de modo a melhorar as condições urbanísticas e ambientais em relação à situação de ocupação informal anterior; $b$ ) criar unidades imobiliárias compatíveis com o ordenamento territorial urbano e constituir sobre elas direitos reais em favor dos seus ocupantes; c) ampliar o acesso à terra urbanizada pela população de baixa renda, de modo a priorizar a permanência dos ocupantes nos próprios núcleos urbanos informais regularizados; $d$ ) promover a integração social e a geração de emprego e renda; e) estimular a resolução extrajudicial de conflitos, inclusive por meio da mediação e da conciliação, em reforço à consensualidade e à cooperação entre Estado e sociedade, em claro intuito de desjudicialização; f) garantir o direito social à moradia digna e às condições de vida adequadas, nos termos do art. $6^{\circ}$ da Constituição Federal; g) garantir a efetivação da função social da propriedade, atendendo ao que consta do art. $5^{\circ}$, inc. XXIII, do Texto Maior; $h$ ) ordenar o pleno desenvolvimento das funções sociais da cidade e garantir o bem-estar de seus habitantes (art. 182 da CF/1988); i) concretizar o princípio constitucional da eficiência na ocupação e no uso do solo; j) prevenir e desestimular a formação de novos núcleos urbanos informais; $k$ ) conceder direitos reais, preferencialmente em nome da mulher, como já estava previsto na Lei 11.977/2009; I) franquear participação dos interessados nas etapas do processo de regularização fundiária, democratizando a distribuição da terra urbana.

A aprovação municipal da Regularização Fundiária Urbana, tratada nesse último comando, corresponde à aprovação urbanística do projeto de regularização fundiária, bem como à aprovação ambiental, se o Município tiver órgão ambiental capacitado (art. 12 da Lei 13.465/2017). Para tanto, considera-se órgão ambiental capacitado o órgão municipal que possua em seus quadros ou à sua disposição profissionais com atribuição técnica para a análise e a aprovação dos estudos de impacto ambiental, independentemente da existência de convênio com os Estados ou a União $\left(\S 1^{\circ}\right)$. Tais estudos ambientais deverão ser elaborados 
por profissional legalmente habilitado e compatibilizar-se com o projeto de regularização fundiária $\left(\S 2^{\circ}\right)$. A norma estabelece, ainda, que os estudos de impacto ambiental aplicam-se somente às parcelas dos núcleos urbanos informais situadas nas áreas de preservação permanente, nas unidades de conservação de uso sustentável ou nas áreas de proteção de mananciais. Eles poderão ser feitos em fases ou etapas, sendo que a parte do núcleo urbano informal não afetada por esses estudos poderá ter seu projeto aprovado e levado a registro separadamente $\left(\S 3^{\circ}\right)$. Por fim, a respeito do tema, está previsto que tal aprovação ambiental da REURB poderá ser feita pelos Estados na hipótese de o Município não dispor de capacidade técnica para a aprovação dos estudos de impactos ambientais ( $\S 4^{\circ}$ da Lei 13.465/2017). Todas essas regras visam à tutela do Bem Ambiental, nos termos do que consta do art. 225 do Texto Maior e da Lei 6.938/1981.

O art. 11 da Lei 13.465/2017 traz os conceitos fundamentais para o fim de implementação da REURB, sendo importante expor os principais.

O primeiro deles é o de núcleo urbano, definido como o assentamento humano, com uso e características urbanas, constituído por unidades imobiliárias de área inferior a um módulo urbano, independentemente da propriedade do solo, ainda que situado em área qualificada ou inscrita como rural. Sabe-se que a extensão de cada módulo urbano é fixada pelo Município, de acordo com o seu plano diretor, que visa atender à função social das cidades (art. 182 da Constituição Federal).

O segundo conceito a ser destacado é o núcleo urbano informal, tido como o clandestino, irregular, ou no qual não foi possível realizar, por qualquer modo, a titulação de seus ocupantes, ainda que atendida a legislação vigente à época de sua implantação ou regularização. Esse imóvel não é desejado pela nova lei, que procura sempre a sua regularização, por institutos que ainda serão aqui demonstrados. O mesmo se diga quanto ao núcleo urbano informal consolidado, aquele de difícil reversão, considerados o tempo da ocupação, a natureza das edificações, a localização das vias de circulação e a presença de equipamentos públicos, entre outras circunstâncias a serem avaliadas pelo Município. Entre as últimas categorias situamse, muitas vezes, as áreas favelizadas.

Para os imóveis em situação de informalidade, o mesmo art. 11 da Lei 13.465/2017 consagra a possibilidade de demarcação urbanística, que vem a ser o procedimento destinado a identificar os bens públicos e privados que assim se encontram, e obter a anuência dos respectivos titulares de direitos inscritos na matrícula dos imóveis ocupados, culminando com averbação na matrícula desses imóveis da viabilidade da regularização fundiária, a ser promovida a critério do Município. Como se nota, entre os entes públicos, o Município é o grande protagonista da nova legislação em comento.

Em seguida, o mesmo comando conceitua a legitimação de posse, com visto, definindo também o novel instituto da legitimação fundiária, como um mecanismo de reconhecimento da aquisição originária do direito real de propriedade sobre unidade imobiliária objeto da REURB, e que será mais à frente estudada.

Por derradeiro, há o conceito na norma de ocupante, aquele que mantém o poder de fato sobre lote ou fração ideal de terras públicas ou privadas em núcleos urbanos informais (art. 11, inc. VIII, da Lei 13.465/2017). Penso que esse pode ser tanto o possuidor (art. 1.198 do Código Civil) como também o detentor (art. 1.198 do Código Civil), definido o último como aquele que tem a coisa em nome de outrem, com quem mantém relação de dependência. Nota-se que o dispositivo utiliza termo que dá certa legitimidade para aquele que tem o poder de fato sobre o bem, sendo comum usar a expressão ocupante com essa finalidade, ao contrário da locução invasor. Em muitos casos de conflitos que dizem respeito à propriedade, as expressões em destaque são utilizadas em sentidos antagônicos, de análise positiva e negativa da situação em que se encontra o imóvel. O ocupante tem certa legitimidade, o invasor não. O legislador, assim, parece ter feito um julgamento prévio.

Ainda trazendo conceitos fundamentais sobre a REURB, o art. 13 da Lei 13.465/2017 enuncia que essa nova política compreende duas modalidades. A primeira delas é a REURB de Interesse Social (REURB-S), definida como a regularização fundiária aplicável aos núcleos urbanos informais ocupados, predominantemente, por população de baixa renda, assim declarados em ato do Poder Executivo municipal. Mais uma vez, aqui se enquadram perfeitamente as áreas favelizadas. Com o fim de tornar possível tal política 
social e proteger os possuidores desfavorecidos economicamente, tidos como hipossuficientes econômicos, o $\S 1^{\circ}$ do dispositivo estatui que serão isentos de custas e emolumentos, entre outros, os seguintes atos registrais relacionados à REURB-S: a) o primeiro registro da REURB-S, que confere direitos reais aos seus beneficiários; $b$ ) o registro da legitimação fundiária; $c$ ) o registro do título de legitimação de posse e a sua conversão em título de propriedade; $d$ ) o registro da Certidão de Regularização Fundiária e do projeto de regularização fundiária, com abertura de matrícula para cada unidade imobiliária urbana regularizada; e) a primeira averbação de construção residencial, desde que respeitado o limite de até setenta metros quadrados $\left(70 \mathrm{~m}^{2}\right)$; f) a aquisição do primeiro direito real sobre unidade imobiliária derivada da REURB-S, caso do domínio pleno sobre imóvel; $g$ ) o primeiro registro do direito real de laje e $h$ ) o fornecimento de certidões de registro para os atos previstos anteriormente. Os cartórios que desobedecerem tal regra estarão submetidos às penas legais (art. $13, \S 6^{\circ}$, da Lei 13.465/2017).

A segunda modalidade é a REURB de Interesse Específico (REURB-E), definida como a regularização fundiária aplicável aos núcleos urbanos informais ocupados por população não qualificada como de baixa renda. Em casos tais, não haverá a incidência dos benefícios acima referidos, relativos aos emolumentos e despesas. Porém, nas duas modalidades, não há necessidade de demonstração do pagamento de tributos ou penalidades tributárias pelo interessado, sendo vedado ao oficial de registro de imóveis exigir sua comprovação para que siga ao procedimento de regularização, sob as penas da lei (art. $13, \S \S 2^{\circ} \mathrm{e}$ $6^{\circ}$, da Lei 13.465/2017).

Seguindo na exposição e breve análise do comando, o $\S 4^{\circ}$ do art. 13 da norma emergente preceitua que, na política de Regularização Fundiária Urbana, em qualquer uma das duas modalidades, os Municípios e o Distrito Federal poderão admitir o uso misto de atividades como forma de promover a integração social e a geração de emprego e renda no núcleo urbano informal regularizado. Assim, não há a exigência de que o imóvel seja utilizado apenas para moradia, sendo possível também a presença de uma pequena atividade comercial ou empresarial na área.

A classificação do interesse visa exclusivamente à identificação dos responsáveis pela implantação ou adequação das obras de infraestrutura essencial e ao reconhecimento do direito à gratuidade das custas e emolumentos notariais e registrais em favor daqueles a quem for atribuído o domínio das unidades imobiliárias regularizadas (art. 13, § 5 , da Lei 13.465/2017). Não se podem classificar os imóveis com outra finalidade, que não seja de ordem puramente econômica, quanto aos benefícios concedidos pela norma emergente.

$\mathrm{O}$ art. 14 da Lei 13.465/2017 elenca as entidades que podem requerer o projeto de REURB, em qualquer uma das suas modalidades. São elas: a) a União, os Estados, o Distrito Federal e os Municípios, diretamente ou por meio de entidades da administração pública indireta; $b$ ) os seus beneficiários, individual ou coletivamente, diretamente ou por meio de cooperativas habitacionais; associações de moradores; fundações; organizações sociais; organizações da sociedade civil de interesse público ou outras associações civis que tenham por finalidade atividades nas áreas de desenvolvimento urbano ou regularização fundiária urbana; c) os proprietários de imóveis ou de terrenos, loteadores ou incorporadores; d) a Defensoria Pública, em nome dos beneficiários hipossuficientes; e e) o Ministério Público. Louva-se a menção expressa à Defensoria Pública, muitas vezes relegada ou esquecida pelo legislador.

Outro dispositivo importante a respeito da REURB é o que estabelece o rol dos institutos jurídicos que pode ser empregado para a sua efetivação. Trata-se do art. 15 da Lei 13.465/2017, que traz claramente um rol exemplificativo, ou numerus apertus, ao utilizar o termo "sem prejuízo de outros que se apresentem adequados, os seguintes institutos jurídicos". São eles: a) a legitimação fundiária e a legitimação de posse; b) a usucapião imobiliária, nas modalidades ordinária, extraordinária, constitucional urbana individual ou coletiva, incluindo a via extrajudicial, que também foi incrementada pela nova lei; $c$ ) a desapropriação judicial privada por posse-trabalho (art. 1.228, $\S \S 4^{\circ}$ e $5^{\circ}$, do $\mathrm{CC} / 2002$ ); d) a arrecadação de bens vagos, prevista no art. 1.276 do Código Civil, e que também teve regulamentação pela norma; e) o consórcio imobiliário, previsto no Estatuto da Cidade, agora com modificações; f) a desapropriação por interesse social, tema de interesse direto do Direito Administrativo; $g$ ) o direito de preempção, preferência ou prelação legal para o Poder Público adquirir a área, previsto no art. 26, inc. I, do Estatuto da Cidade (Lei 10.257/2001); $h$ ) a transferência 
do direito de construir, nos termos do art. 35, inc. III, do mesmo Estatuto da Cidade; $h$ ) a requisição, em caso de perigo público iminente, nos termos do $\S 3^{\circ}$ do art. 1.228 do Código Civil; i) a intervenção do poder público em parcelamento clandestino ou irregular (art. 40 da Lei 6.766/1979); j) a alienação de imóvel pela administração pública diretamente para seu detentor; $k$ ) a concessão de uso especial para fins de moradia; l) a concessão de direito real de uso; $m$ ) a doação; e $n$ ) a compra e venda. Todos esses institutos devem ser incrementados para afastar as situações irregulares dos imóveis urbanos, constituindo-se em uma tentativa do legislador de, enfim, obter a necessária regularização das áreas favelizadas.

Expostas essas regras gerais sobre a REURB, muito mais descritivas do que efetivas, vejamos o estudo do instituto da legitimação fundiária, categoria totalmente inédita no Direito Civil Brasileiro.

\section{Do novo instituto da legitimação fundiária}

Nos termos do art. 23 da Lei 13.465/2017, a legitimação fundiária constitui forma originária de aquisição do direito real de propriedade conferido por ato do Poder Público, exclusivamente no âmbito da REURB. Tal direito é concedido àquele que detiver em área pública ou possuir em área privada, como sua, unidade imobiliária com destinação urbana, integrante de núcleo urbano informal consolidado existente até 22 de dezembro de 2016.

Conforme o $\S 1^{\circ}$ do mesmo preceito, a legitimação fundiária somente será concedida no âmbito da REURB-S se preenchidos os seguintes requisitos: a) o beneficiário não pode ser concessionário, foreiro ou proprietário de imóvel urbano ou rural; $b$ ) o beneficiário não pode ter sido contemplado com legitimação de posse ou fundiária de imóvel urbano com a mesma finalidade, ainda que situado em núcleo urbano distinto; e c) em caso de imóvel urbano com finalidade não residencial, que seja reconhecido pelo Poder Público o interesse público de sua ocupação.

Por meio da legitimação fundiária, o ocupante adquire a unidade imobiliária com destinação urbana livre e desembaraçada de quaisquer ônus, direitos reais, gravames ou inscrições, eventualmente existentes em sua matrícula de origem, exceto quando disserem respeito ao próprio legitimado (art. $23, \S 2^{\circ}$, da Lei 13.465/2017). Diante dessa regra, confirma-se a afirmação segundo a qual a aquisição originária da propriedade, aquela em que há o contato direto entre a pessoa e a coisa, zera o domínio jurídico, fazendo desaparecer tudo o que nele incide, como é o caso das garantias reais e dos tributos que recaiam sobre o imóvel. Está também previsto que deverão ser transportadas as inscrições, as indisponibilidades ou os gravames existentes no registro da área maior originária para as matrículas das unidades imobiliárias que não houverem sido adquiridas por legitimação fundiária (art. 23, § $3^{\circ}$, da Lei 13.465/2017).

Conforme me informou pessoalmente Carlos Eduardo Elias de Oliveira, assessor jurídico do Senado Federal e que participou da elaboração da lei, o objetivo do instituto, ao ser tratado como forma originária de aquisição da propriedade, é de plena regularização, por parte do Poder Público Municipal, de áreas populares ou favelizadas. Atribuem-se as áreas a particulares sem que exista a necessidade de pagamento de impostos, notadamente do ITCMD, que os Estados geralmente cobram quando o Município transmite a propriedade a ser regularizada. Nas suas palavras, o que gerou o instituto foi a existência de numerosas ocupações irregulares, somada às pretensões dos Municípios de regularizá-las. Na opinião deste autor, trata-se de um instituto que se situa entre a legitimação da posse e a usucapião.

Aguardemos o futuro, para a verificação de sua efetividade ou não, na prática do Direito Civil, caso a Lei 13.465/2017 não tenha a sua inconstitucionalidade reconhecida. Não vejo maiores problemas quando a legitimação fundiária recaia sobre bem público. Porém, em casos relativos a imóveis privados, pode-se sustentar que a atribuição da legitimação fundiária representa verdadeiro atentado contra o direito fundamental de propriedade. Nesse sentido posiciona-se Victor Carvalho Pinto (2017, p. 5-6), também assessor jurídico no Senado Federal, para quem

[...] a legitimação fundiária (art. 23), que é a principal inovação trazida pela MPV e mantida na Lei, é uma grave violação do direito de propriedade, constitucionalmente assegurado, pois faculta ao prefeito conferir a terceiros a propriedade de imóveis por eles ocupados, sem indenização aos 
proprietários e independentemente do tempo e da natureza da posse. No caso de áreas públicas, a legitimação fundiária viola, ainda, a vedação expressa da Constituição à usucapião de bens públicos. Em conjugação com dispositivos que dispensam a alienação de bens públicos em geral e da União em particular, de desafetação, licitação, autorização legislativa e avaliação prévia, a Lei compromete a defesa do patrimônio público, as prerrogativas do Poder Legislativo, a transparência da gestão pública e a responsabilidade fiscal.

No caso dos bens públicos, com o devido respeito, não vejo problemas, pois entendo que tais imóveis também estão sujeitos ao princípio da função social, sendo até possível a usucapião de bens públicos dominicais. $^{3}$

Como palavras finais deste tópico: não se pode negar que o instituto já nasce controverso, e com sérias objeções apresentadas, não sem a devida razão.

\section{Mudanças quanto à usucapião extrajudicial decorrente da legitimação da posse}

A citada Lei 11.977/2009 - conhecida como Lei Minha Casa, Minha Vida - instituiu modalidade de usucapião administrativa ou extrajudicial, decorrente da legitimação da posse, a ser efetivada no Cartório de Registro de Imóveis, dispensando demanda judicial. Reitere-se que a categoria da legitimação da posse recebeu modificações substanciais por força da Lei 13.465/2017, que revogou os dispositivos legais relativos ao tratamento anterior e incluiu novos comandos.

De acordo com a nova norma, como visto, a legitimação de posse passou a ser definida como o ato do Poder Público destinado a conferir título, por meio do qual fica reconhecida a posse de imóvel objeto da política de Regularização Fundiária Urbana (REURB). Essa posse qualificada é conversível em aquisição de direito real de propriedade, com a identificação de seus ocupantes, do tempo da ocupação e da natureza da posse (art. 11, inc. VI, da Lei 13.465/2017).

A norma revogada, art. 59 da Lei 11.977/2009, previa que o Poder Público poderia legitimar a posse de ocupantes de imóveis públicos ou particulares ("A legitimação de posse devidamente registrada constitui direito em favor do detentor da posse direta para fins de moradia"). Tal legitimação da posse seria concedida aos moradores cadastrados pelo Poder Público, desde que: a) não fossem concessionários, foreiros ou proprietários de outro imóvel urbano ou rural; e b) não fossem beneficiários de legitimação de posse concedida anteriormente. A legitimação de posse também seria concedida ao coproprietário da gleba, titular de cotas ou frações ideais, devidamente cadastrado pelo Poder Público, desde que exercesse seu direito de propriedade em um lote individualizado e identificado no parcelamento registrado.

Após concessão de tal direito, estabelecia o art. 60 da Lei 11.977/2009 que o detentor do título de legitimação de posse, após 5 (cinco) anos de seu registro, poderia requerer ao oficial de registro de imóveis a conversão desse título em registro de propriedade, tendo em vista sua aquisição por usucapião, nos termos do art. 183 da Constituição Federal. Em outras palavras, convertia-se a mera legitimação da posse em domínio jurídico pleno por meio da usucapião especial ou constitucional urbana individual, desde que preenchidos os requisitos que estão ali, repetidos pelo art. 1.240 do Código Civil, a saber: i) posse ad usucapionem sobre área urbana de até duzentos e cinquenta metros por cinco anos, ininterruptamente e sem oposição; ii) utilização do imóvel para a moradia do possuidor ou de sua família, o que justifica a sua denominação como usucapião pro misero ou pro moradia; iii) o usucapiente não pode ser proprietário de outro imóvel urbano ou rural; e iv) esse direito à usucapião somente pode ser reconhecido uma vez a cada possuidor que o pleiteia.

Sempre ressaltei, em comentários à realidade jurídica anterior, que, no caso de bens públicos, em tese, não seria cabível tal conversão, diante da proibição que consta do $\S 3^{\circ}$ do art. 183 do Texto Maior e do art. 102 do CC/2002, exceção feita apenas para os bens públicos dominicais. Para requerer tal conversão,

3 Como desenvolvo em: TARTUCE, Flávio. Direito civil. 10. ed. Rio de Janeiro: Forense, 2018. v. 4: Direito das coisas, capítulo 3. 
o adquirente deveria apresentar: a) certidões do cartório distribuidor demonstrando a inexistência de ações em andamento que versassem sobre a posse ou a propriedade do imóvel; $b$ ) declaração de que não possuía outro imóvel urbano ou rural; c) declaração de que o imóvel era utilizado para sua moradia ou de sua família; e $d$ ) declaração de que não tinha reconhecido anteriormente o direito à usucapião de imóveis em áreas urbanas. Se a área fosse superior a $250 \mathrm{~m}^{2}$, não seria possível adquiri-la pela modalidade da usucapião especial ou constitucional urbana, mas apenas por outra categoria, caso da usucapião ordinária ou da extraordinária (art. 60 , § $3^{\circ}$, da Lei 11.977/2009).

Por fim, o título de legitimação de posse poderia ser extinto pelo Poder Público emitente quando constatado que o beneficiário não estava na posse do imóvel e quando não houvesse registro de cessão de direitos. Após o procedimento para extinção do título, o Poder Público solicitaria ao oficial de registro de imóveis a averbação do seu cancelamento (art. 60-A da Lei 11.977/2009).

Tendo sido revogados expressamente todos esses comandos, a legitimação da posse e a consequente usucapião administrativa estão agora tratadas entre os arts. 25 a 27 da Lei 13.465/2017. Repise-se que, nos termos do primeiro comando, a legitimação de posse, instrumento de uso exclusivo para fins de regularização fundiária, constitui ato do Poder Público destinado a conferir título, por meio do qual fica reconhecida a posse de imóvel objeto da Regularização Fundiária Urbana. Nesse ato constará a identificação de seus ocupantes, o tempo da ocupação e a natureza da posse, sendo conversível em direito real de propriedade.

Nos termos do art. $25, \S 1^{\circ}$, da Lei $13.465 / 2017$, a legitimação de posse poderá ser transferida por causa mortis ou por ato inter vivos. Trata-se de uma expressão de novidade na abordagem do instituto, apesar de o art. 60-A da Lei 11.977/2009 abrir a possibilidade de sua cessão. Agora, sem qualquer dúvida, é juridicamente viável a transmissão inter vivos da legitimação da posse com natureza onerosa, o que pode trazer sérios problemas sociais, diante das notórias práticas de especulação imobiliária em nosso País.

Ademais, está previsto no $\S 2^{\circ}$ do art. 25 da Lei 13.465/2017 que a legitimação de posse não se aplica aos imóveis urbanos situados em área de titularidade do Poder Público. Fecha-se, portanto, qualquer possibilidade de usucapião administrativa sobre bens públicos dominicais, dúvida que poderia ser levantada no sistema anterior, por falta de previsão legal específica. De todo modo, reiteramos que essa já era a conclusão retirada do art. $183, \S 3^{\circ}$, do Texto Maior e do art. 102 do Código Civil, como antes destacado.

Conforme o art. 26 da Lei 13.465/2017, sem prejuízo dos direitos decorrentes do exercício da posse mansa e pacífica no tempo, aquele em cujo favor for expedido título de legitimação de posse, decorrido o prazo de cinco anos de seu registro, terá a conversão automática dele em título de propriedade, por meio da usucapião constitucional urbana individual, desde que atendidos os termos e as condições do art. 183 da Constituição Federal. Agora, por expressa previsão, tal conversão independe de prévia provocação ou prática de ato registral. Como se nota, ao contrário do que constava do art. 60 da Lei 11.977/2009, em casos tais não haverá necessidade de qualquer manifestação do oficial do Cartório do Registro de Imóveis, sendo a citada conversão automática, ou seja, pleno iure.

Porém, caso não estejam preenchidos os requisitos para a usucapião constitucional urbana individual, o título de legitimação de posse poderá ser convertido em título de propriedade, desde que satisfeitos os requisitos de outras modalidades de usucapião estabelecidos na legislação em vigor, a requerimento do interessado, perante o Cartório de Registro de Imóveis competente, do local de situação do imóvel (art. $26, \S 1^{\circ}$, da Lei 13.465/2017). A título de ilustração, caso a hipótese fática seja de usucapião ordinária, seja extraordinária, caberá sua conversão administrativa mediante pedido ao oficial do Cartório de Registro de Imóveis, que decidirá sobre o preenchimento dos seus requisitos ou não. Não há mais menção quanto aos documentos que devem ser apresentados, o que depende de regulamentação administrativa pelas respectivas Corregedorias Gerais de Justiça dos Estados, que disciplinam a atuação dos cartórios. Caso isso não ocorra, a decisão de exigência cabe ao registrador de imóveis.

A legitimação de posse, após convertida em propriedade, constitui forma originária de aquisição de direito real. Diante dessa realidade jurídica, a unidade imobiliária com destinação urbana regularizada restará livre e desembaraçada de quaisquer ônus, direitos reais, gravames ou inscrições eventualmente existentes em sua matrícula de origem, exceto quando disserem respeito ao próprio beneficiário (art. $26, \S$ 
$2^{\circ}$, da Lei 13.465/2017). A nova previsão confirma, mais uma vez, a afirmação de que as formas originárias de aquisição da propriedade zeram o domínio jurídico, fazendo desaparecer todos os gravames que recaiam sobre o bem, caso dos impostos, das despesas condominiais e das garantias reais, como a hipoteca.

Quanto ao cancelamento do título da legitimação de posse pelo Poder Público, esse poderá ocorrer quando constatado que as condições estipuladas na nova lei deixaram de ser satisfeitas, sem que seja devida qualquer indenização àquele que irregularmente se beneficiou do instrumento (art. 27 da Lei 13.465/2017). Como visto, a Lei Minha Casa, Minha Vida estabelecia que a legitimação da posse seria extinta pelo Poder Público quando constatado que o beneficiário não estava na posse do imóvel e não houvesse registro de cessão de direitos. Agora, a lei utiliza um parâmetro mais abrangente, estabelecendo que caberá sua extinção toda vez que o instituto não esteja sendo utilizado para os fins de Regularização Fundiária Urbana.

Como se pode perceber, amplas foram as modificações realizadas pela nova lei a respeito dessa modalidade de usucapião administrativa. Todavia, a verdade é que a categoria da usucapião extrajudicial sequer chegou a encontrar a devida estabilidade e aplicação prática esperada na vigência da Lei 11.977/2009. Assim, parece ter razão o Ministério Público Federal em sua petição inicial da ação de inconstitucionalidade proposta em face da nova lei, ao alegar que os Municípios, já adaptados à realidade da Lei Minha Casa, Minha Vida, terão que se readequar ao novo sistema, causando muitas dúvidas e incertezas.

\section{Novas modalidades de condomínio: condomínio de lotes e condomínio urbano simples}

Novamente, com o intuito de melhorar a qualidade da distribuição da terra urbana, visando à formalização dominial de muitas áreas e com o objetivo de resolver problemas e dilemas anteriores, a Lei 13.465/2017 introduziu novas modalidades de condomínio, a saber: a) o condomínio de lotes, incluindo a modalidade de acesso controlado; e b) o condomínio urbano simples.

Começando pelo condomínio de lotes, a norma emergente incluiu, por força do seu art. 58, uma seção no tratamento relativo ao condomínio na codificação material (art. 1.358-A do CC/2002). O objetivo foi de alcançar os chamados loteamentos fechados, regulamentando-os e atribuindo-Ihes formalidade. Conforme o caput do preceito, pode haver, em terrenos, partes designadas de lotes que são propriedade exclusiva e partes que são propriedade comum dos condôminos.

Observa-se que os loteamentos de casas passam a seguir, sem qualquer dúvida, o mesmo regime do condomínio edilício, com a divisão em áreas comuns - de convivência de todos -, e exclusivas - com posse direta exercida somente por cada um dos condôminos. Acrescente-se que o conceito de loteamento é retirado do art. $2^{\circ}, \S 1^{\circ}$, da Lei $6.766 / 1979$, que trata do parcelamento do solo urbano. Nos seus termos, considera-se loteamento a subdivisão de gleba em lotes destinados a edificação, com abertura de novas vias de circulação, de logradouros públicos ou prolongamento, modificação ou ampliação das vias existentes.

Também conforme a lei especial, o lote é definido como o terreno servido de infraestrutura básica, cujas dimensões atendam aos índices urbanísticos definidos pelo plano diretor ou lei municipal para a zona em que se situa (art. $2^{\circ}, \S 4^{\circ}$, da Lei 6.766/1979). Como mecanismos de infraestrutura, há previsão quanto aos equipamentos urbanos de escoamento das águas pluviais, iluminação pública, esgotamento sanitário, abastecimento de água potável, energia elétrica pública e domiciliar e vias de circulação (art. $2^{\circ}, \S 5^{\circ}$, da Lei 6.766/1979).

Expostos tais conceitos básicos, estabelece o novo $\S 1^{\circ}$ do art. 1.358-A do Código Privado que a fração ideal de cada condômino poderá ser proporcional à área do solo de cada unidade autônoma, ao respectivo potencial construtivo ou a outros critérios indicados no ato de instituição. Segue-se, assim, o modelo do condomínio edilício, notadamente o que consta do art. $1.331, \S 3^{\circ}$, da própria codificação material, segundo o qual "a cada unidade imobiliária caberá, como parte inseparável, uma fração ideal no solo e nas outras partes comuns, que será identificada em forma decimal ou ordinária no instrumento de instituição do condomínio". Nos dois casos poderão as partes envolvidas dispor sobre a fração ideal de cada condômino, o que representa importante e fundamental valorização da autonomia privada.

Em complemento, como avanço, preceitua o novo $\S 2^{\circ}$ do art. 1.358-A do CC/2002 que se aplica, no que couber, ao condomínio de lotes, o disposto sobre condomínio edilício neste Capítulo, respeitada a 
legislação urbanística. Assim, entendo que se resolve o problema anterior a respeito da obrigatoriedade do pagamento das contribuições no condomínio de lotes. Com a aplicação das regras gerais do condomínio edilício, cada condômino do loteamento de casas estará sujeito aos deveres previstos no art. 1.336 do Código Civil e às penalidades ali consagradas, inclusive para os casos de condômino nocivo ou antissocial, tratado no comando seguinte. ${ }^{4}$

Supera-se, portanto, decisão anterior do Supremo Tribunal Federal que concluiu pela não incidência das regras relativas ao condomínio edilício no tocante à cobrança de taxas de administração para os condomínios fechados de casas, tratados como associações de moradores (STF, RE 432.106, $1^{\text {a }}$ Turma, Rel. Min. Marco Aurélio, j. 20.09.2011). Igualmente, está superada a posição consolidada no Superior Tribunal de Justiça, em julgamento de incidente de recursos repetitivos, praticamente pacificando a questão (REsp 1.280.871/SP e REsp 1.439.163/SP, $2^{\text {a }}$ Seção, Rel. Min. Ricardo Villas Bôas Cueva, Rel. para acórdão Min. Marco Buzzi, j. 11.03.2015, DJe 22.05.2015, publicado no seu Informativo n. 562).

A minha posição sempre foi no mesmo sentido do Enunciado n. 89 da I Jornada de Direito Civil, evento promovido pelo Conselho da Justiça Federal em 2002, in verbis: "O disposto nos arts. 1.331 a 1.358 do novo Código Civil aplica-se, no que couber, aos condomínios assemelhados, tais como loteamentos fechados, multipropriedade imobiliária e clubes de campo". O teor da proposta doutrinária, salvo melhor juízo, parece compor o novo art. 1.358-A, $\S 2^{\circ}$, do Código Civil. Sendo assim, a jurisprudência superior deve se posicionar de maneira diferente a partir da vigência da Lei 13.465/2017, determinando a obrigatoriedade do pagamento das contribuições nos condomínios de lotes, sob pena das sanções estabelecidas no art. 1.336 do Código Civil.

Questão de debate levantada pela nova lei diz respeito ao regime aplicado para a instituição desse condomínio de lotes, se pela Lei 4.591/1964 (Lei de Incorporações) ou pela Lei 6.766/1979 (Lei do Parcelamento do Solo Urbano). Em palestra ministrada na Associação dos Advogados de São Paulo, em 17 de janeiro de 2018, o professor Rodrigo Toscano de Brito defendeu a premissa de submissão à primeira lei, incidindo os requisitos formais de instituição, previstos no seu art. 32, e sendo possível - e recomendável, pela segurança jurídica -, a instituição de patrimônio de afetação. ${ }^{5}$

CC/2002. "Art. 1.336. São deveres do condômino: I - contribuir para as despesas do condomínio na proporção das suas frações ideais, salvo disposição em contrário na convenção; (Redação dada pela Lei n. 10.931, de 2004); II - não realizar obras que comprometam a segurança da edificação; III - não alterar a forma e a cor da fachada, das partes e esquadrias externas; IV - dar às suas partes a mesma destinação que tem a edificação, e não as utilizar de maneira prejudicial ao sossego, salubridade e segurança dos possuidores, ou aos bons costumes. $\S 1^{\circ} \mathrm{O}$ condômino que não pagar a sua contribuição ficará sujeito aos juros moratórios convencionados ou, não sendo previstos, os de um por cento ao mês e multa de até dois por cento sobre o débito. $\S 2^{\circ} \mathrm{O}$ condômino, que não cumprir qualquer dos deveres estabelecidos nos incisos II a IV, pagará a multa prevista no ato constitutivo ou na convenção, não podendo ela ser superior a cinco vezes o valor de suas contribuições mensais, independentemente das perdas e danos que se apurarem; não havendo disposição expressa, caberá à assembleia geral, por dois terços no mínimo dos condôminos restantes, deliberar sobre a cobrança da multa. Art. 1.337. O condômino, ou possuidor, que não cumpre reiteradamente com os seus deveres perante o condomínio poderá, por deliberação de três quartos dos condôminos restantes, ser constrangido a pagar multa correspondente até ao quíntuplo do valor atribuído à contribuição para as despesas condominiais, conforme a gravidade das faltas e a reiteração, independentemente das perdas e danos que se apurem. Parágrafo único. O condômino ou possuidor que, por seu reiterado comportamento antissocial, gerar incompatibilidade de convivência com os demais condôminos ou possuidores, poderá ser constrangido a pagar multa correspondente ao décuplo do valor atribuído à contribuição para as despesas condominiais, até ulterior deliberação da assembleia".

5 A redação do art. 32 da Lei 4.591/1964 é a seguinte: "Art. 32. O incorporador somente poderá negociar sobre unidades autônomas após ter arquivado, no cartório competente de Registro de Imóveis, os seguintes documentos: a) título de propriedade de terreno, ou de promessa, irrevogável e irretratável, de compra e venda ou de cessão de direitos ou de permuta do qual conste cláusula de imissão na posse do imóvel, não haja estipulações impeditivas de sua alienação em frações ideais e inclua consentimento para demolição e construção, devidamente registrado; $b$ ) certidões negativas de impostos federais, estaduais e municipais, de protesto de títulos de ações cíveis e criminais e de ônus reais relativamente ao imóvel, aos alienantes do terreno e ao incorporador; c) histórico dos títulos de propriedade do imóvel, abrangendo os últimos 20 anos, acompanhado de certidão dos respectivos registros; d) projeto de construção devidamente aprovado pelas autoridades competentes; e) cálculo das áreas das edificações, discriminando, além da global, a das partes comuns, e indicando, para cada tipo de unidade a respectiva metragem de área construída; f) certidão negativa de débito para com a Previdência Social, quando o titular de direitos sobre o terreno for responsável pela arrecadação das respectivas contribuições; $g$ ) memorial descritivo das especificações da obra projetada, segundo modelo a que se refere o inciso IV, do art. 53 , desta Lei; $h$ ) avaliação do custo global da obra, atualizada à data do arquivamento, calculada de acordo com a norma do inciso III, do art. 53 com base nos custos unitários referidos no art. 54, discriminando-se, também, o custo de construção de cada unidade, devidamente autenticada pelo profissional responsável pela obra; i) discriminação das frações ideais de terreno com as unidades autônomas que a elas corresponderão; j) minuta da futura Convenção de condomínio que regerá a edificação ou o conjunto de edificações; l) declaração em que se defina a parcela do preço de que trata o inciso II, do art. $39 ; m)$ certidão do instrumento público de mandato, referido no $\S 1^{\circ}$ do artigo $31 ; n$ ) declaração expressa em que se fixe, se houver, o prazo de carência (art. 34); o) atestado de idoneidade financeira, fornecido por estabelecimento de crédito que opere no País há mais de cinco anos; $p$ ) declaração, acompanhada de plantas elucidativas, sobre o número de veículos que a garagem comporta e os locais destinados à guarda dos mesmos. (Alínea incluída pela Lei n. 4.864, de 29.11.1965)". O patrimônio de afetação está previsto no art. 31-A da Lei 4.591/1964, tendo sido incluído pela Lei 10.931/2004. De acordo com a sua previsão principal, "a critério do incorporador, a incorporação poderá ser submetida ao regime da afetação, pelo qual o terreno e as acessões objeto de incorporação imobiliária, bem como os demais bens e direitos a ela vinculados, manterse-ão apartados do patrimônio do incorporador e constituirão patrimônio de afetação, destinado à consecução da incorporação correspondente e à entrega das unidades imobiliárias aos respectivos adquirentes". 
Esse entendimento, contudo, está longe de pacífico. Carlos Eduardo Elias de Oliveira (2017), por exemplo, sustenta a aplicação do regime da segunda lei citada - a Lei do Parcelamento do Solo Urbano -, aplicando-se apenas subsidiariamente a Lei de Incorporações. ${ }^{6}$ Nesse debate, fico com a posição do professor Toscano de Brito, uma vez que o condomínio de lotes passa a estar submetido ao mesmo sistema do condomínio edilício, sendo a incorporação imobiliária o mecanismo correto para as suas instituições.

Encerrando o tratamento na Lei Geral Privada, o $\S 3^{\circ}$ do novo art. 1.358-A prevê que, para fins de incorporação imobiliária, a implantação de toda a infraestrutura ficará a cargo do empreendedor. Novamente, segundo Carlos Eduardo Elias de Oliveira (2017, p. 10), assessor jurídico do Senado Federal e que, repisese, participou do processo de elaboração da Lei 13.465/2017 naquela Casa, o dispositivo é óbvio, mas pode criar potenciais problemas no futuro. Isto porque

[...] é plenamente possível entender que, na realidade, ele se destina a proteger os adquirentes de 'Iotes na planta' (incorporação é vender 'imóveis futuros' que serão incorporados ao solo), de maneira que eventual cláusula inserida nos contratos de alienação feitas pelo incorporador poderá ser tida por nula se deixar as obras de infraestrutura para serem executadas pelos compradores dos lotes.

Na sequência de seu texto, o jurista propõe uma interpretação restritiva do comando, por entender que

[...] ele se destina apenas a proteger o interesse público de que o condomínio de lotes não crie uma área desértica e sem o suporte adequado. Daí decorre que esse dispositivo não impede o incorporador de repassar os custos ou a obrigação de fazer essas obras aos compradores dos lotes. Esse repasse, porém, não exonerará o incorporador de responder perante a Administração Pública por omissões na realização dessas obras, ressalvado - se for o caso - o direito de regresso contra os compradores dos lotes (OLIVEIRA, 2017, p. 10-11).

Essa também é a minha opinião, em especial quanto às responsabilidades do incorporador perante o Poder Público.

Além da regra inserida no Código Civil, outras normas sobre o condomínio de lotes merecem comentários. De início, o art. 45 da Lei 13.465/2017 enuncia que, quando se tratar de imóvel sujeito a regime de condomínio geral a ser dividido em lotes com indicação, na matrícula, da área deferida a cada condômino, o Município poderá indicar, de forma individual ou coletiva, as unidades imobiliárias correspondentes às frações ideais registradas, sob sua exclusiva responsabilidade, para a especialização das áreas registradas em comum. O seu objetivo, sem dúvidas, é de regularizar os loteamentos fechados, com o aval do Município, como antes foi exposto. Com tom suplementar, se as informações referidas não constarem do projeto de regularização fundiária aprovado pelo Município, as novas matrículas das unidades imobiliárias serão abertas mediante requerimento de especialização, formulado pelos interessados, dispensada a outorga de escritura pública para indicação da quadra e do lote (parágrafo único desse art. 45 da Lei 13.465/2017).

Outras alterações importantes foram feitas na já citada Lei 6.766/1979. No seu art. $2^{\circ}$, que traz conceitos fundamentais sobre o parcelamento do solo urbano, foi incluído o $\S 7^{\circ}$, segundo o qual o lote poderá ser constituído sob a forma de imóvel autônomo ou de unidade imobiliária integrante de condomínio de lotes. Assim, podem ser visualizadas no artigo duas modalidades de loteamento. A primeira delas é o loteamento tradicional, em que os lotes são imóveis autônomos.

\footnotetext{
6 Nas suas lições, "o condomínio de lotes deverá ser fruto de um parcelamento do solo. Afinal de contas, é um condomínio de... lotes! O próprio art. $2^{\circ}, \S 7^{\circ}$, da Lei n. 6.766/1979 estabelece que o lote poderá ser constituído como um imóvel autônomo (que é a forma tradicional de lote até hoje conhecida) ou como uma unidade imobiliária integrante de um condomínio de lotes. O lote continua sendo um imóvel próprio, com direito a uma matrícula própria no Cartório de Imóveis, em observância ao princípio da unitariedade matricial. Todavia, o conceito de lote se ampliou. Isso significa que, para a criação de um condomínio de lotes, necessariamente devem ser observados todos os procedimentos da Lei de Loteamentos, como a exigência de aprovação prévia do município. A Lei n. 6.766/79, portanto, é plenamente aplicável para disciplinar também o condomínio de lotes. Ora, essa lei já possui regras para disciplinar os casos de venda de 'lotes na planta', ou seja, de lotes que ainda serão edificados, razão por que podemos levantar a seguinte indagação: a Lei de Incorporação Imobiliária (Lei n. 4.591/64) também seria aplicável? Incorporação imobiliária é alienar unidades autônomas de um condomínio que ainda será construído e instituído. É, grosso modo, alienar 'imóvel na planta'. Portanto, se alguém haverá de construir um prédio e instituir um condomínio edilício sem alienar precocemente qualquer uma das unidades, não há falar em incorporação imobiliária. Ao nosso sentir, a Lei de Incorporação Imobiliária é vocacionada a preparar a instituição de condomínios no futuro, de modo que ela tem de ser também observada no condomínio de lotes. Nesse sentido, o próprio $\S 3^{\circ}$ do art. $1.358-A$ do CC fez remissão expressa à incorporação imobiliária. Seja como for, entendemos que a Lei n. 4.591/64 deve ser aplicada para suprir lacunas da Lei de Loteamentos. Em outras palavras, a sua aplicação deve ser subsidiária" (OLIVEIRA, 2017, p. 11-12).
} 
A segunda modalidade é o loteamento condominial, situação na qual os lotes constituem unidades autônomas de um condomínio. Para essa modalidade, estatui o novo art. $4^{\circ}$, $\S 4^{\circ}$, da Lei $6.766 / 1979$ que poderão ser instituídos limitações administrativas e direitos reais sobre coisa alheia em benefício do Poder Público, da população em geral e da proteção da paisagem urbana, tais como servidões de passagem, usufrutos e restrições à construção de muros. Isso para tornar viável o convívio do loteamento condominial com a sociedade, atendendo à sua função social. Entre todas as restrições, a que mais ocorre na prática é a servidão de passagem. Eventualmente, se o loteamento encravar algum outro imóvel, é possível a presença do instituto da passagem forçada, tratado no art. 1.285 do Código Civil.

Há ainda o loteamento de acesso controlado, tratado pelo novo $\S 8^{\circ}$ do art. $2^{\circ}$ da Lei 6.766/1979, cujo controle de acesso será regulamentado por ato do Poder Público municipal. Em casos tais, é vedado o impedimento de acesso a pedestres ou a condutores de veículos não residentes, devidamente identificados ou cadastrados, o que depende de regulamentação por cada Município, mais uma vez, para atender à função social da propriedade.

A encerrar o estudo do condomínio de lotes, o art. 36-A da Lei 6.766/1976, também incluído pela Lei $13.465 / 2017$, prevê que as atividades desenvolvidas pelas associações de proprietários de imóveis, titulares de direitos ou moradores em loteamentos ou empreendimentos assemelhados, desde que não tenham fins lucrativos, bem como pelas entidades civis organizadas em função da solidariedade de interesses coletivos desse público com o objetivo de administração, conservação, manutenção, disciplina de utilização e convivência, visando à valorização dos imóveis que compõem o empreendimento, tendo em vista a sua natureza jurídica, vinculam-se, por critérios de afinidade, similitude e conexão, à atividade de administração de imóveis. Essa vinculação, penso, torna mais uma vez obrigatório o pagamento das contribuições no condomínio de lotes, a incluir a modalidade de acesso controlado.

Partindo para o estudo do condomínio urbano simples, prescreve o art. 61 da Lei 13.465/2017 que, quando um mesmo imóvel contiver construções de casas ou cômodos, poderá ser instituído, inclusive para fins de REURB, condomínio urbano simples. Nessa instituição, devem ser respeitados os parâmetros urbanísticos locais. Devem também ser discriminadas, na matrícula, a parte do terreno ocupada pelas edificações, as partes de utilização exclusiva e as áreas que constituem passagem para as vias públicas ou para as unidades entre si. Em relação à categoria, aplica-se o disposto na própria lei que o instituiu e, em complemento e no que couber, o disposto entre os arts. 1.331 a 1.358 do Código Civil. Assim, novamente, reconhece-se a subsunção subsidiária das regras relativas ao condomínio edilício.

Mais uma vez, segundo pontua Carlos Eduardo Elias de Oliveira (2017, p. 17), embora a categoria tenha recebido nova nomenclatura,

trata-se, na realidade, de uma espécie de condomínio edilício que dispensa algumas formalidades em razão da sua pequena dimensão. Esse condomínio aplica-se a situações de terrenos onde haja mais de uma construção e em que o seu titular queira tornar cada uma dessas construções uma unidade autônoma de condomínio. Diante da sua simplicidade, o condomínio urbano simples dispensa a apresentação de convenção de condomínio.

O assessor do Senado Federal esclarece, em continuidade, que a expressão "cômodos" foi mal empregada, devendo ser entendida como um complemento à menção a "construções". De fato, em uma primeira leitura, parece que a norma está tratando de condomínio dentro de um mesmo imóvel supostamente com habitação coletiva, o popular cortiço, também conhecido como pensão de quartos. Todavia, esse não é o caso, ainda segundo o mesmo autor, que pontua duas situações possíveis para o condomínio urbano simples. A primeira delas ocorre quando o terreno contiver várias edificações, como acontece na chamada "casa dos fundos". A segunda situação está presente quando o terreno contiver uma edificação na qual haja "mais de um cômodo com acesso autônomo". ${ }^{7}$ Com o devido respeito, tenho que melhor refletir a questão,

E arremata: "não se pode admitir o condomínio urbano simples para cômodos que estejam funcional e espacialmente conectados, como no caso de quartos de um mesmo apartamento. É preciso haver autonomia funcional e de acesso no cômodo para ele constituir uma unidade autônoma de condomínio urbano simples" (OLIVEIRA, 2017, p. 17) 
pois, a priori, não parece haver óbice em se reconhecer a presença de um condomínio urbano simples nas habitações coletivas.

Conforme o art. 62 da Lei 13.465/2017, a instituição do condomínio urbano simples será registrada na matrícula do respectivo imóvel. Nesse registro, assim como ocorre com o condomínio edilício, serão identificadas as partes comuns ao nível do solo, as partes comuns internas à edificação, se houver, e as respectivas unidades autônomas, dispensada a apresentação de convenção de condomínio, como antes exposto.

Após o registro da instituição do condomínio urbano simples, deverá ser aberta uma matrícula própria para cada unidade autônoma. A cada uma dessas matrículas caberá, como parte inseparável, uma fração ideal do solo e das outras partes comuns, se houver, representada na forma de percentual (art. $62, \S 1^{\circ}$, da Lei 13.465/2017). As unidades autônomas constituídas em matrícula própria poderão ser alienadas e gravadas livremente por seus titulares, como ocorre com o condomínio edilício (art. 62, § $2^{\circ}$, da Lei 13.465/2017). Na linha da posição doutrinária por último transcrita, a norma expressa que nenhuma unidade autônoma poderá ser privada de acesso ao logradouro público (art. 62, $\S 3^{\circ}$, da Lei 13.465/2017). Afastar-se-ia a impressão de que se trata de condomínio em habitação coletiva, importante matéria de dúvida, como antes se apontou. Quanto à gestão das partes comuns, essa será feita de comum acordo entre os condôminos, podendo ser formalizada por meio de instrumento particular (art. 62, § $3^{\circ}$, da Lei 13.465/2017). Penso que há a plena possibilidade de os condôminos escolherem um administrador ou síndico, bem como compor um conselho fiscal, como ocorre com o condomínio edilício.

Por derradeiro, a novel legislação exprime que, no caso da REURB-S - regularização fundiária aplicável aos núcleos urbanos informais ocupados predominantemente por população de baixa renda e assim declarados em ato do Poder Executivo Municipal -, a averbação das edificações poderá ser efetivada a partir de mera notícia, a requerimento do interessado (art. 63 da Lei 13.465/2017). Dessa notícia registral constarão a área construída e o número da unidade imobiliária, dispensada a apresentação de Habitese e de certidões negativas de tributos e contribuições previdenciárias. A dispensa do Habite-se merece críticas, pois muitas vezes a sua ausência diz respeito a problemas estruturais que acometem o imóvel. Ademais, tenho sérias dúvidas se os registradores de imóveis receberão com bons olhos a citada notícia. Essa também foi a opinião do professor Rodrigo Toscano de Brito, em palestra ministrada na Associação dos Advogados de São Paulo, em janeiro de 2018, que apontou a necessidade de sua regulamentação por normas administrativas das Corregedorias Estaduais.

Como palavras finais, mais uma vez é necessário aguardar se essa nova categoria terá, de fato, a devida efetivação na realidade prática brasileira. Apesar de críticas, notadamente quanto ao último instituto, acredito que o novo tratamento apenas visa a regulamentar algo que já vinha ocorrendo na prática social brasileira. ${ }^{8}$ Quanto ao conteúdo dos dispositivos, não vejo maiores problemas técnicos, sendo elogiável, para as duas novas modalidades de condomínio, a aproximação em relação ao condomínio edilício.

\section{Do direito real de laje}

Como um dos seus aspectos fundamentais, a Lei 13.465/2017 introduziu um tratamento relativo à laje, além de sua previsão no rol dos direitos reais, previsto no art. 1.225 do Código Civil (inc. XIII). O objetivo da introdução do instituto, mais uma vez, é de regularização de áreas favelizadas, conhecidas popularmente como comunidades. O tema já havia sido abordado por grandes juristas no âmbito do direito de superfície, com uso dessa expressão popular e de cunho social, que ganhou certo apego jurídico. Entre eles, podem ser citados os professores Ricardo Pereira Lira, Rodrigo Reis Mazzei e Marco Aurélio Bezerra de Melo. Em

O advogado André Abelha (2017, online), por exemplo, faz um trocadilho com a categoria, denominando-a "condomínio urbano simples(mente absurdo)" e afirmando que o instituto "saiu do nada, e vai a lugar nenhum, não passando de uma forma equivocada de se apelidar, sem nenhuma base jurídica, o condomínio edilício”. 
muitas localidades brasileiras, como ocorre no Rio de Janeiro, as lajes são "vendidas", ou seja, transferidas onerosamente e de forma definitiva para terceiros. Também é comum a sua transmissão gratuita, entre pessoas da mesma família, que pretendem morar no mesmo prédio, muitos deles no popular puxadinho.

Entendo que a norma trouxe grandes avanços devido a sua Medida Provisória embrionária, a MP 759/2016, que foi alvo de muitas críticas doutrinárias. Confrontando o texto da MP e a nova lei, constatase que a primeira introduzia apenas um dispositivo no Código Civil, o art. 1.510-A, com oito parágrafos. A Lei 13.465/2017, muito mais abrangente, inclui os arts. 1.510-A a 1.510-E na codificação material, tendo o primeiro preceito a mesma quantidade de parágrafos. A principal crítica que se fazia à norma era o fato de conceituar o direito real de laje como "a possibilidade de coexistência de unidades imobiliárias autônomas de titularidades”. Como pontuam Pablo Stolze Gagliano e Salomão Viana (2017, p. 2),

[...] houve, aqui, manifesto aprimoramento, em relação ao texto da Medida Provisória $n^{0} 759$, de 22 de dezembro de 2016. Efetivamente, do texto anterior, que não era preciso, extraía-se a definição do direito de laje como uma 'possibilidade de coexistência'. Com efeito, não se afigura adequado conceituar um direito real como uma 'possibilidade.

Com mesma opinião, são bem conhecidas as críticas anteriores formuladas por Otávio Luiz Rodrigues Júnior (2016), que participou do processo de elaboração da nova norma, para quem o tratamento constante da Medida Provisória não tinha o menor sentido jurídico. ${ }^{9}$

O caput do atual art. 1.510-A do Código Civil estabelece que "O proprietário de uma construção-base poderá ceder a superfície superior ou inferior de sua construção a fim de que o titular da laje mantenha unidade distinta daquela originalmente construída sobre o solo". Resolveu-se o citado problema da atecnia, sobre a possibilidade, mas foi criado outro, esse sim de natureza técnica profunda. A grande dúvida quanto ao novo tratamento legal diz respeito ao fato de ser a laje um direito real sobre coisa própria ou sobre coisa alheia. A forma de tratamento dada pelo Código Civil não ajuda a resolver tal dilema, uma vez que a laje foi inserida após o tratamento dos direitos reais de garantia sobre coisa alheia, fechando o livro do direito das coisas.

Realizando pesquisa em textos publicados na internet e consultando diretamente alguns colegas juristas, a questão, de fato, é tormentosa e divide a doutrina contemporânea. Assim, são adeptos da existência de um direito real sobre coisa própria: Marco Aurélio Bezerra de Melo, Nelson Rosenvald, Fernando Sartori, Fábio Azevedo, Carlos Eduardo Elias de Oliveira, Leonardo Brandelli, Vitor Kümpel e Bruno de Ávila Borgarelli. Por outra via, entendendo existir um direito real sobre coisa alheia: José Fernando Simão, Pablo Stolze Gagliano, Rodolfo Pamplona Filho, Salomão Viana, Cristiano Chaves de Farias, Frederico Viegas de Lima, Maurício Bunazar, Cesar Calo Peghini, Eduardo Busatta, Alexandre Barbosa, Luciano Figueiredo, João Ricardo Brandão Aguirre, Pablo Malheiros da Cunha Frota, Rodrigo Toscano de Brito e Rodrigo Reis Mazzei. ${ }^{10}$ Vejamos os argumentos de uma e outra corrente.

Entre os que entendem tratar-se de direito real sobre coisa própria, Carlos Eduardo Elias de Oliveira (2017, p. 6) argumenta que

[...] a natureza jurídica é esclarecida pela leitura dos arts. 1.510-A e seguintes do Código Civil e do novo $\S 9^{\circ}$ que foi acrescido ao art. 176 da Lei de Registros Públicos (conforme art. 56 da nova Lei). Na forma como foi redigido o Código Civil nesse ponto, o Direito Real de Laje é uma espécie de Direito Real de Propriedade sobre um espaço tridimensional que se expande a partir da laje de uma construção-base em direção ascendente ou a partir do solo dessa construção em direção subterrânea. Esse espaço tridimensional formará um poliedro, geralmente um paralelepípedo ou um

\footnotetext{
Segundo o jurista, "especificamente quanto ao Código Civil, o artigo 25 da MP 759, de 2016, alterou a redação do artigo 1.225 do código, ao incluir o inciso XIII, que institui a 'laje' como novo direito real. A laje é definida no novo artigo 1.510-A, de um modo extremamente atécnico. A laje é um direito real que 'consiste na possibilidade de coexistência de unidades imobiliárias autônomas de titularidades distintas situadas em uma mesma área, de maneira a permitir que o proprietário ceda a superfície de sua construção a fim de que terceiro edifique unidade distinta daquela originalmente construída sobre o solo'. Um direito que é uma possibilidade! Trata-se de uma nova categoria, a qual se recomenda ao estudo nos cursos de Filosofia" (RODRIGUES JR., 2016, online).

10 Em palestra ministrada na Associação dos Advogados de São Paulo, no dia 22 de janeiro de 2018, Rodrigo Mazzei afirmou categoricamente que a laje é uma modalidade de direito real de superfície.
} 
cubo. A figura geométrica dependerá da formatação da sua base de partida e também dos limites impostos no ato de instituição desse direito real e das regras urbanísticas. Teoricamente, esse espaço poderá corresponder a um poliedro em forma de pirâmide ou de cone, se isso for imposto no ato de instituição ou em regras urbanísticas. Esse espaço pode ser suspenso no ar quando o direito real for instituído sobre a laje do prédio existente no terreno ou pode ser subterrâneo quando o direito real for instituído no subsolo. Enfim, o Direito de Laje é um Direito Real de Propriedade e faculta ao seu titular todos os poderes inerentes à propriedade (usar, gozar e dispor), conforme art. 1.510-A, $\S 3^{\circ}$, do Código Civil.

Como se nota da leitura do trecho transcrito, o assessor jurídico do Senado Federal traz uma simbologia geométrica interessante para demonstrar a ideia de laje como direito real sobre coisa própria. Como argumento suplementar, pontua o mesmo autor que se trata de um direito real sobre coisa própria pelo fato de existir a abertura de uma matrícula própria, após a sua transmissão, nos termos do art. 1.510-A, $\S 3^{\circ}$, do $\mathrm{CC} / 2002$ e do novo art. 176 , $\S 9^{\circ}$, da Lei de Registros Públicos, também incluído pela Lei 13.465/2017. Conforme o último dispositivo, "a instituição do direito real de laje ocorrerá por meio da abertura de uma matrícula própria no registro de imóveis e por meio da averbação desse fato na matrícula da construçãobase e nas matrículas de lajes anteriores, com remissão recíproca". Argumenta que, se o direito de laje fosse um direito real sobre coisa alheia, não poderia gerar matrícula própria. Na doutrina existem vozes que trazem outros argumentos. ${ }^{11}$

Em sentido contrário, muitos juristas sustentam que há uma grande proximidade do direito real de laje com a superfície, o que justifica o seu reconhecimento como direito real sobre coisa própria, argumento que, a priori, convence este autor. Ademais, parece-nos, como bem pontuado por José Fernando Simão em debates sobre o tema, que o proprietário da construção-base, ora denominado cedente ou lajeiro, mantém o direito de reaver a estrutura da coisa, da construção-base, o que acaba por englobar também a laje. $O$ cessionário, ou lajeário, tendo um direito real sobre coisa alheia, não tem o direito de reivindicá-la contra terceiro, mas apenas de ingresso de demandas possessórias. Com o devido respeito, a abertura de uma matrícula própria, aspecto formal e acessório, não tem a força de mudar a natureza jurídica da categoria, para direito real sobre coisa própria.

Nessa mesma linha posicionam-se Pablo Stolze Gagliano e Rodolfo Pamplona Filho (2017, p. 1116), para quem

[...] diferentemente de outros direitos reais na coisa alheia, o direito de laje tem, em seu conteúdo, um singular animus, equiparável ao de domínio, embora não se caracterize, pela sua estrutura peculiar, como direito real na coisa própria (propriedade), na medida em que, derivando de mera cessão de uso, gratuita ou onerosa, da superfície do imóvel que lhe é inferior, resulta na coexistência de unidades autônomas em uma mesma área. Em síntese, o sujeito a quem a laje se vincula não deve ser considerado 'proprietário' da unidade construída, mas sim titular do direito real de laje sobre ela, o que lhe concederá faculdades amplas, similares àquelas derivadas do domínio.

As lições transcritas foram citadas em recente julgado do Superior Tribunal de Justiça, publicado em setembro de 2017, que já aborda o novo tratamento legislativo e conclui pela presença de um direito real sobre coisa alheia (publicado no Informativo n. 610 da Corte).

11 Vitor Frederico Kümpel e Bruno de Ávila Borgarelli (2017, online) seguem o entendimento de que se trata de um direito real sobre coisa própria. Segundo as suas lições, que aqui merecem destaque: "Na realidade, prefere-se ver o direito de laje como direito real sobre coisa própria. Recorde-se que o direito real sobre coisa própria é aquele em que há uma unidade de poder, toda ela circunscrita a um único titular, que é exatamente o caso da laje. Não há uma divisão de poder, como ocorre nos direitos reais sobre coisa alheia de fruição, garantia ou aquisição. Não há dois titulares; o titular do imóvel-base não guarda vínculo jurídico real com o titular da laje superior ou inferior. O que há entre eles são direitos e deveres, na medida em que existem áreas comuns, tal qual ocorre nos direitos de vizinhança (o que será visto na próxima coluna). A relação jurídica estabelecida entre o titular da propriedade da construção-base e os titulares das lajes é grandemente informada pelo negócio jurídico constitutivo do direito em discussão. Derivam-se efeitos no plano obrigacional, ordinariamente. Não se está a negar que o negócio jurídico molde uma parte da relação jurídica real. Essa questão se relaciona à ampliação dos poderes negociais em termos de modulação das situações reais, fenômeno usualmente reconduzido ao contemporâneo enfraquecimento do princípio da tipicidade dos direitos reais (ou ao que quer que se entenda por essa chamativa rubrica). Mas o eventual espaço para essa autorregulamentação não é capaz de influenciar decisivamente a qualificação do direito real (isto é, sua colocação junto a uma daquelas duas principais categorias dos direitos reais). Tanto menos no caso do direito real de laje. Uma vez edificada a construção sobreposta (ou subterrânea), aberta a matrícula e registrado o imóvel em nome do pretendente, consolida-se a situação jurídica marcada pelo exercício exclusivo de poderes sobre a unidade". 
Trata-se de demanda que investiga a presença de vícios redibitórios em área de suposta laje, concluindo que "apesar de realmente ter-se reconhecido um vício oculto inicial, a coisa acabou por não ficar nem imprópria para o consumo, nem teve o seu valor diminuído, justamente em razão do saneamento posterior, que permitiu a construção do gabarito nos termos em que contratado. Ademais, não houve a venda de área em extensão inferior à prometida, já que o direito de uso de dois pavimentos - inferior e cobertura - acabou sendo efetivamente cumprido, perdendo fundamento o pedido estimatório inicial, notadamente por não ter a coisa perdido seu valor, já que recebida em sua totalidade" (BRASIL. STJ, REsp 1.478.254/RJ, Rel. Min. Luis Felipe Salomão, $4^{\mathrm{a}}$ Turma, j. 08.08.2017, DJe 04.09.2017). ${ }^{12}$ Advirta-se que, ao final, a decisão afasta a caracterização da situação como direito real de laje, nos termos do tratamento que foi dado pela novel legislação. Conforme o voto do Ministro Relator:

No entanto, a presente hipótese, apesar de também ser conhecida como 'laje', não se tipifica ao novel instituto, já que se está, em verdade, diante de uma projeção de parte ideal do mesmo apartamento - o terraço cobertura (espécie de acessão/benfeitoria) - de titularidade única, com o mesmo número de matrícula, sem desdobramento da propriedade, não se tratando de unidade autônoma nem funcionalmente independente.

O que merece ser destacado, nesse primeiro pronunciamento do Superior Tribunal de Justiça sobre o tema, é o reconhecimento da laje como direito real sobre coisa alheia, na linha da vertente doutrinária que sigo.

Seguindo no estudo do novo tratamento constante do Código Civil, o $\S 1^{\circ}$ do art. 1.510-A prescreve que o direito real de laje contempla o espaço aéreo ou o subsolo de terrenos públicos ou privados, tomados em projeção vertical, como unidade imobiliária autônoma. Porém, a laje não contempla as demais áreas edificadas ou não pertencentes ao proprietário da construção-base. Há, assim, grande proximidade com a superfície prevista no Estatuto da Cidade, uma vez que o art. $21, \S 1^{\circ}$, da Lei 10.257/2001 determina que "o direito de superfície abrange o direito de utilizar o solo, o subsolo ou o espaço aéreo relativo ao terreno, na forma estabelecida no contrato respectivo, atendida a legislação urbanística".

Também como ocorre com a superfície, o titular do direito real de laje - cessionário ou lajeário responderá pelos encargos e tributos que incidirem sobre a sua unidade (art. 1.510-A, $\S 2^{\circ}$, do CC/2002). Entendo que se trata de mais uma norma de ordem privada, podendo haver disposição em sentido contrário, por acordo entre as partes, dividindo as despesas de forma proporcional, por exemplo.

Como visto, a cessão da laje autoriza a abertura de matrícula própria (art. 1.510-A, § $3^{\circ}$, do CC). Os titulares ou cessionários da laje poderão dela usar, gozar e dispor. A norma não menciona o direito de reaver ou reivindicar por parte do lajeário, pois esse permanece com o cedente ou proprietário da construção-base (lajeiro). Aqui há, claramente, um fundamento legal importante para a posição de que se trata de um direito real sobre coisa alheia e não sobre coisa própria.

Também a conduzir a tal dedução, está expresso na lei que a instituição do direito real de laje não implica a atribuição de fração ideal de terreno ao titular da laje ou a participação proporcional em áreas já edificadas (art. 1.510-A, $\S 4^{\circ}$, do CC). Não há, portanto, a existência de um condomínio entre as partes envolvidas, ou seja, internamente. Entretanto, as partes do direito real de laje, especialmente o cessionário, devem respeitar, externamente, as regras condominiais impostas ao imóvel, caso este se localize em edifício sob esse regime. Nesse sentido, o novo art. 1.510-C do Código Civil é claro ao dispor que

[...] sem prejuízo, no que couber, das normas aplicáveis aos condomínios edilícios, para fins do direito real de laje, as despesas necessárias à conservação e fruição das partes que sirvam a todo o edifício e ao pagamento de serviços de interesse comum serão partilhadas entre o proprietário da construção-base e o titular da laje, na proporção que venha a ser estipulada em contrato.

\footnotetext{
Ainda segundo o Relator, Ministro Salomão, ao analisar as inclusões feitas pela Lei 13.465/2017, "o foco da norma foi o de regulamentar realidade social muito comum nas cidades brasileiras, conferindo, de alguma forma, dignidade à situação de inúmeras famílias carentes que vivem alijadas de uma proteção específica, dando maior concretude ao direito constitucional à moradia (CF, art. $\left.6^{\circ}\right)$. Criou-se, assim, um direito real sobre coisa alheia (CC, art. 1.510-A), no qual se reconheceu a proteção sobre aquela extensão - superfície sobreposta ou pavimento inferior - da construção original, conferindo destinação socioeconômica à referida construção" (BRASIL. STJ, REsp 1.478.254/RJ, Rel. Min. Luis Felipe Salomão, $4^{a}$ Turma, j. 08.08.2017, DJe 04.09.2017).
} 
Eis outra norma de ordem privada que admite previsão em sentido contrário, entre as partes envolvidas com a laje. Quando a lei menciona o termo "contrato", entende-se negócio jurídico, pois não há um contrato no sentido categórico do tema, mas um direito real. Ademais, a laje pode ser criada por outros negócios não contratuais, caso do testamento.

O mesmo dispositivo elenca quais são as partes estruturais que servem todo o edifício, o que guarda similaridade com as partes comuns do condomínio edilício. Nos termos do $\S 1^{\circ}$ do art. $1.510-C$ da codificação privada, são elas: i) os alicerces, colunas, pilares, paredes-mestras e todas as partes restantes que constituam a estrutura do prédio; ii) o telhado ou os terraços de cobertura, ainda que destinados ao uso exclusivo do titular da laje; iii) as instalações gerais de água, esgoto, eletricidade, aquecimento, ar condicionado, gás, comunicações e semelhantes que sirvam a todo o edifício; e iv) em geral, as coisas que sejam afetadas ao uso de todo o edifício, caso de escadas externas que dão acesso aos vários andares do prédio, inclusive às lajes.

Em qualquer caso, a lei assegura aos interessados o direito de promover reparações urgentes na construção, na forma do parágrafo único do art. 249 da própria Norma Geral Privada (art. 1.510-C, § $2^{\circ}$, do CC/2002). A norma mencionada no preceito diz respeito à autotutela civil das obrigações de fazer fungível, cabível nos casos de urgência, independentemente de autorização judicial. De acordo com o seu conteúdo, aplicado para a categoria em estudo, presente a necessidade de um reparo na laje, um dos interessados pode fazê-lo diretamente, cobrando em momento posterior o valor correspondente à outra parte interessada. Em regra, reconhece-se a divisão igualitária das despesas, diante da máxima concursu partes fiunt. Porém, cedente e cessionário podem dispor internamente em sentido contrário. Não se pode esquecer que o exercício de tal direito de reparo não pode configurar abuso, servindo como parâmetro o art. 187 da própria codificação privada.

Voltando ao art. 1.510-A, prevê o seu $\S 5^{\circ}$ que os Municípios e o Distrito Federal poderão dispor sobre posturas edilícias e urbanísticas associadas ao direito real de laje. Valem as regras relativas ao plano diretor de cada cidade, visando a sua função social, nos termos do que consta do art. $2^{\circ}$ da Lei 10.257/2001 (Estatuto da Cidade) e do art. 182 da Constituição Federal de 1988. A título de exemplo, as normas municipais podem limitar o número de lajes, a altura das construções ou mesmo proibi-las em algumas localidades, por oferecerem riscos à população, como em áreas íngremes.

O titular da laje poderá ceder a superfície de sua construção para a instituição de um sucessivo direito real de laje. Tal cessão somente é possível se houver autorização expressa dos titulares da construçãobase e das demais lajes, respeitadas, mais uma vez, as posturas edilícias e urbanísticas vigentes (art. 1.510-A, $\S 6^{\circ}$, do Código Civil). Pontue-se que a MP 759/2016 vedava a possibilidade de lajes sucessivas ou sobrelevação, o que contrariava a posição doutrinária então existente, liderada por Ricardo Pereira Lira e Rodrigo Mazzei, no tratamento da superfície. A solução agora é outra, tendo o apoio deste autor, desde que as novas construções não tragam riscos, não só para os envolvidos com o direito real, mas também a terceiros e para a sociedade como um todo. ${ }^{13}$

Porém, em todos os casos, é expressamente vedado ao titular da laje prejudicar, com obras novas ou com falta de reparação a segurança, a linha arquitetônica ou o arranjo estético do edifício, observadas

\footnotetext{
3 Como bem leciona Carlos Eduardo Elias de Souza (2017, p. 08) sobre o último comando, "daí decorre que, por meio das lajes sucessivas, poderse-á ter várias unidades autônomas sobrepostas em linha ascendente (espaço aéreo) ou descendente (subsolo). A laje de primeiro grau é a que, em primeiro lugar, repousa sobre ou sob a construção-base. A de segundo grau é a que segue após a laje de primeiro grau. E assim sucessivamente. De qualquer forma, como a laje sucessiva pressupõe uma laje anterior (a de segundo grau presume, por exemplo, a laje de primeiro grau), é pressuposto inafastável que haja uma construção já realizada no caso de direitos reais de lajes no espaço aéreo. Em outras palavras, somente se poderá registrar um direito real de laje de segundo grau se, na matrícula da laje anterior, já tiver sido averbada alguma construção. Não se pode estabelecer direitos reais de lajes sucessivos no espaço aéreo sem a existência material e concreta de uma construção. A propósito, uma prova de que a existência concreta de construção é requisito para o direito real de laje no espaço aéreo é a previsão expressa de extinção da laje no caso de ruína do prédio sem posterior reedificação (art. 1.510-E, CC). É diferente do que sucede com as lajes subterrâneas, pois, como o subsolo possui existência concreta, não há necessidade de se exigir uma prévia averbação de uma construção na laje anterior. Veja que a ruína da construção não extingue os direitos de lajes subterrâneas exatamente em razão da intangibilidade desse espaço (art. 1.510-E, I, CC)". $\mathrm{Na}$ linha das palavras transcritas, podem coexistir, perfeitamente e em um mesmo edifício, lajes de primeiro e de segundo grau, sejam de forma ascendente - para o espaço aéreo -, ou descendente - para o subsolo.
} 
as posturas previstas em legislação local, o que mais uma vez é repetição de norma prevista para o condomínio edilício (art. 1.510-C do Código Civil). O desrespeito a essa regra possibilita o ingresso de uma ação de obrigação de fazer ou de não fazer por parte daqueles que se sentirem prejudicados, caso do cedente ou dos proprietários de lajes anteriores. Vale lembrar que, nos termos do art. 497, parágrafo único, do CPC/2015, presente eventual ilícito, a concessão de medidas de tutela específica em tais ações independe da prova de culpa, dolo ou dano.

Seguindo, como inovação salutar, a lei estabelece um direito de preferência bilateral, do cedente e do cessionário, em casos de alienação de qualquer uma das unidades sobrepostas (art. 1.510-D do Código Civil). Essa preferência é em igualdade de condições de terceiros, havendo uma ordem legal, no sentido de primeiro se atribuir a preferência aos titulares da construção-base (lajeiros) e depois aos titulares da laje (lajeários). O beneficiário da preferência deverá ser cientificado por escrito para que se manifeste no prazo decadencial de trinta dias, salvo se o negócio jurídico instituidor da laje dispuser de forma contrária.

Na opinião deste autor, o prazo previsto em lei constitui um lapso temporal mínimo, podendo apenas ser aumentado, e não diminuído. Vale lembrar que os prazos de decadência podem ser alterados por convenção das partes (decadência convencional), o que não ocorre na prescrição. Quanto à cientificação ou notificação da outra parte, a sua forma é livre, desde que escrita, podendo ser feita judicialmente, por meio de Cartório de Títulos e Documentos, por carta com aviso de recebimento ou mesmo de modo eletrônico, desde que possa ser posteriormente comprovado.

Ainda conforme $\circ \S^{\circ}$ do art. 1.510-D do Código Civil, o titular da construção-base ou da laje a quem não se der conhecimento da alienação poderá, mediante depósito do respectivo preço, haver para si a parte alienada a terceiros, se o requerer no prazo decadencial de cento e oitenta dias, contado da data de alienação. Ao contrário do que ocorreu com a superfície, na linha do que foi antes demonstrado, o legislador foi feliz ao estabelecer a consequência caso uma das partes seja preterida no seu direito de preferência, bem como ao estabelecer o início do prazo decadencial para o ingresso da ação adjudicatória. Sem qualquer dúvida, no tocante à laje, seguiu-se a mesma solução existente na venda de coisa comum ou em condomínio, tratada pelo art. 504 do próprio Código Civil.

Entretanto, se houver mais de uma laje, terão preferência, sucessivamente, os titulares das lajes ascendentes e depois os titulares das lajes descendentes, assegurada a prioridade para a laje mais próxima à unidade sobreposta a ser alienada (art. 1.510-D, §2 ${ }^{\circ}$ do CC/2002). De forma didática, sendo vários os preferentes, pode-se dizer que a preferência sobe, para depois descer, e que a laje mais próxima exclui a mais remota.

A última regra inserida no Código Civil é o seu art. 1.510-E, que trata da extinção do direito real de laje pela ruína da construção-base. A norma traz duas exceções para essa extinção. A primeira delas diz respeito à laje instituída sobre o subsolo, o que, por motivos físicos, não gera a sua extinção. Nos termos da lei, a segunda hipótese de exceção é "se a construção-base não for reconstruída no prazo de cinco anos". Como muitos já perceberam, parece-nos que a expressão negativa destacada foi mal empregada. $\mathrm{Na}$ verdade, a norma quer dizer que, se a construção-base for reconstruída no prazo decadencial de cinco anos, não haverá a extinção do direito real em questão.

De todo modo, a última norma não afasta o direito a eventual reparação civil contra o culpado pela ruína (art. 1.510-E, parágrafo único, do CC/2002). Vale lembrar que, nos termos do art. 937 do Código Civil, o dono do prédio ou construção responde objetivamente por sua ruína. A última norma também não afasta a responsabilidade subjetiva, mediante culpa, daquele que foi o real causador do evento danoso na relação entre cedente e cessionário.

Expostas e analisadas as regras previstas no Código Civil, faz-se importante comentar dois dispositivos que foram incluídos no Código de Processo Civil pelo art. 57 da Lei 13.465/2017. Tratam-se de dois incisos que foram acrescentados ao art. 799 do CPC/2015, que regulamenta incumbências de intimação pelo exequente na ação de execução. Nos termos do seu novo inc. $X$, cabe a ele requerer a intimação do titular da construção-base, bem como, se for o caso, do titular de lajes anteriores, quando a penhora recair sobre 
o direito real de laje. E como não poderia ser diferente, conforme o seu inc. XI, ele deve também requerer a intimação do titular das lajes quando a penhora recair sobre a construção-base. Por coerência, segue-se o mesmo modelo estabelecido para a superfície, previsto nos incs. IV e X do mesmo art. 799.14

Analisadas as regras sobre o direito de laje, cabe expor sobre uma polêmica que possivelmente virá, qual seja: a possibilidade de usucapião do direito real de laje, polêmica que atingiu igualmente a superfície, no passado. Assim como ocorre com aquele instituto, estou filiado à corrente que não vê qualquer óbice para a usucapião, assim como ocorre com os demais direitos reais sobre coisa alheia, caso da servidão e do usufruto. Em suma, apesar da falta de previsão específica, penso que é possível a usucapião da laje, nas modalidades a elas adaptadas, inclusive pela via extrajudicial, nos termos do que consta do art. 216-A da Lei de Registros Públicos, incluído pelo CPC/2015 e recentemente alterado pela mesma Lei 13.465/2017.

Para encerrar o estudo da categoria, não se olvide que existem duras críticas a respeito do novo tratamento do direito real de laje. Frederico Viegas de Lima (2017), em comentários à Medida Provisória 759, já afirmava que o tratamento ali constante não teria o condão de, como um passe de mágica, resolver os problemas referentes à propriedade urbana no Brasil. ${ }^{15}$ Sílvio de Salvo Venosa (2017) faz ressalvas ainda mais duras, também duvidando da efetividade prática do instituto que foi positivado. ${ }^{16}$

De fato, volta-se a um dos problemas antes mencionados a respeito das tentativas legislativas de regularização das áreas favelizadas no Brasil. E, aqui, neste momento, não se tem uma bola de cristal jurídica para afirmar que tal dificuldade, até agora intransponível, será superada pelo tratamento relativo à laje instituído pela Lei 13.465/2017.

\section{Conclusão}

Ao início deste trabalho, propus duas questões que deveriam ser respondidas e, que após este estudo, almejo responder, apesar das limitações de tempo, pois a norma ora analisada tem poucos meses de existência.

14 Apesar da clareza dos comandos, Pablo Stolze Gagliano e Salomão Viana (2017, p. 8), em estudo interdisciplinar, demonstram um problema processual nas regras que foram inseridas, que merecem especial atenção. Vejamos suas palavras: "Sucede que o art. 799 do CPC integra, em verdade, um conjunto de dispositivos do qual se extrai um significativo complexo de normas voltadas para a proteção dos interesses de terceiros. Esse conjunto é integrado também pelos arts. 804 e 889 do próprio CPC e os elencos de terceiros constantes em tais dispositivos, malgrado amplo, não é exaustivo. Por meio do complexo normativo extraível dos mencionados dispositivos estabelece-se um quadro de cuidados a serem adotados quando a penhora recai sobre bens que, de algum modo, sofrem reflexos de uma eventual relação jurídica mantida entre um terceiro e o executado. Assim, por exemplo, se a penhora recair sobre um bem gravado por hipoteca, o credor hipotecário deve ser intimado da penhora (CPC, art. 799, I) e cientificado, com pelo menos cinco dias úteis de antecedência, a respeito da data marcada para início do leilão (CPC, art. $889, \mathrm{~V})$, caso contrário o ato de alienação será ineficaz em relação a ele (CPC, art. 804, caput). Situação similar ocorre com todos os terceiros mencionados nos três dispositivos, o que conduz o intérprete à clara - e correta - conclusão de que o mesmo elenco de terceiros deve ser intimado da ocorrência da penhora (CPC, art. 799), também deve ser cientificado a respeito da data designada para início do leilão (CPC, art. 889) e goza da proteção da norma segundo a qual, havendo alienação do bem sem que os mencionados atos de comunicação tenham sido praticados, a alienação será, quanto ao terceiro, ineficaz. É por isso que falhou o legislador: os acréscimos feitos no texto do art. 799 deveriam também ser realizados nos enunciados dos arts. 804 e 889. Não o foram, porém, o que é lamentável. À vista do equívoco cometido, deve o intérprete, portanto, ficar atento e, sempre que se deparar com situações fáticas decorrentes da existência de relação jurídica de direito material entre o executado e terceiro, com algum tipo de reflexo, mesmo indireto, sobre o bem penhorado, lembrar-se de que os elencos mencionados nos arts. 799,804 e 889 , além de não serem exaustivos, comunicam-se entre si”. Essa também é a minha opinião, devendo as mesmas regras serem incluídas nos dispositivos citados, e que não foram expressamente abrangidos, sob pena de as inovações perderem sentido.

15 "No início desse ano, boa parcela do mundo jurídico festejou a introdução na legislação do conhecido direito de laje, tal como fosse uma absoluta novidade, capaz de solucionar vários problemas de moradia existentes em determinadas zonas de nossas grandes cidades, conhecidas por décadas como favelas e que mais recentemente passaram a ser denominadas comunidades, como se a denominação trouxesse alguma modificação instantânea para os graves problemas sociais que ali se encontram" (LIMA, 2017, p. 252).

16 Nas suas palavras, analisando o art. 1.510-A do Código Civil, "a primeira postura interpretativa desse artigo introduzido no Código Civil é identificar o imóvel que a lei denomina construção-base. A lei procurou ordenar e disciplinar as inúmeras construções que vão sendo sobrepostas (ou infrapostas), geralmente sem o menor critério e segurança em agrupamentos urbanos que findam por se tornar as chamadas comunidades, denominação mais Ihana das favelas. O texto admite também a utilização do direito de laje para o piso inferior, ou seja, o subsolo. Nessa disposição excêntrica nosso legislador terceiro-mundista confessa-se como tal bem como se dá por vencido em resolver a problemática habitacional brasileira, para constituir uma modalidade de direito real que mais trará problemas que soluções. Raramente far-se-á registro imobiliário desse direito, mormente porque imóveis desse jaez situam-se em comunidades irregulares, com vasta pressão populacional e sérios problemas de segurança que longe estão de regularização registral. Na verdade, os sambas e versos que cantam as favelas, hoje denominadas comunidades, e mencionam as lajes, são formosos nas estrofes, mas trágicos na realidade". E, ao final, conclui: "espera-se que a instituição desse insólito direito real de laje atinja bons resultados. E que o legislador se preocupe também em resolver por outras formas mais apropriadas e eficientes o vasto problema habitacional brasileiro". (VENOSA, 2017, online). 
A primeira indagação foi a seguinte: a Lei 13.465/2017 conseguirá superar os problemas demonstrados a respeito da regularização dos imóveis urbanos no Brasil e atingir os seus objetivos, ou seja, os seus fins sociais? Como encerrei o tópico anterior, somente o tempo e a prática poderão responder a tal questão. Porém, ressalto que a ausência de políticas públicas para tal fim, especialmente pelo Poder Público Municipal - o grande protagonista da nova norma -, possivelmente fará com que a lei tenha o mesmo destino das tentativas anteriores.

A segunda indagação formulada foi a seguinte: acertou o legislador ao consagrar novas categorias e ao tratar de maneira diferente outras que já eram admitidas pelo nosso Direito? Como ficou claro por este texto, existem acertos e desacertos nas novas regulamentações, cabendo mais uma vez à praxis demonstrar a concretude desses tratamentos emergentes, que alteraram, sem dúvidas, algumas estruturas do instituto da propriedade no Direito Privado Brasileiro.

\section{Referências}

ABELHA, André. Nova Lei 13.465/17 (Parte V): o condomínio urbano simples(mente absurdo). 2017. Disponível em: <http://www.migalhas.com.br/dePeso/16,Ml263359,81042-Nova+lei+1346517+Parte+V+ O+condominio+urbano+simplesmente+absurdo>. Acesso em: 9 jan. 2018.

GAGLIANO, Pablo Stolze; PAMPLONA FILHO, Rodolfo. Manual de direito civil. São Paulo: Saraiva, 2017 (volume único).

GAGLIANO, Pablo Stolze; VIANA, Salomão. Direito real de laje. Finalmente a lei! Artigos de convidados. Disponível em: <www.flaviotartuce.adv.br>. Acesso em: 9 jan. 2018.

KÜMPEL, Vitor Frederico; BORGARELLI, Bruno de Ávila. Algumas reflexões sobre o direito real de laje - Parte I. Disponível em: <www.migalhas.com.br>. Acesso em: 9 jan. 2018.

LIMA, Frederico Viegas de. Direito de laje: uma visão da catedral. Revista de Direito Imobiliário, São Paulo, RT, ano 40, n. 82, p. 251-280, jan./jun. 2017.

LIRA, Ricardo Pereira. Elementos de direito urbanístico. Rio de Janeiro: Renovar, 1997.

LÔBO, Paulo. Direito civil. Coisas. São Paulo: Saraiva, 2015.

MARQUES, Benedito Ferreira. Direito agrário brasileiro. 9. ed. São Paulo: Saraiva, 2011.

MAZZEI, Rodrigo. Direito de superfície. Salvador: Juspodivm, 2013.

MELO, Marco Aurélio Bezerra de. Legitimação de posse: dos imóveis urbanos e o direito à moradia. Rio de Janeiro: Lumen Juris, 2008.

OLIVEIRA, Carlos Eduardo Elias de. Direito real de laje à luz da Lei 13.465/2017: uma nova hermenêutica. Disponível em: <www.flaviotartuce.adv.br>. Acesso em: 9 jan. 2018.

OLIVEIRA, Carlos Eduardo Elias de. Novidades da Lei n. 13.465/2017: o condomínio de lotes, o condomínio urbano simples e o loteamento de acesso controlado. Artigos de convidados. Disponível em: <www.flaviotartuce.adv.br>. Acesso em: 27 set. 2017.

PINTO, Victor Carvalho. A regularização fundiária urbana na Lei 13.465/2017. Disponível em: <https://edisciplinas.usp.br/pluginfile.php/4109237/mod_resource/content/1/A\%20 Regulariza\%C3\%A7\%C3\%A3o\%20Fundi\%C3\%A1ria\%20Urbana\%20na\%20Lei\%2013.465.2017\%20 -\%20Victor\%20Carvalho\%20Pinto.pdf>. Acesso em: 9 jan. 2018.

RODRIGUES JR., Otávio Luiz. Um ano longo demais e os seus impactos no direito civil contemporâneo. Disponível em: <http://www.conjur.com.br/2016-dez-26/retrospectiva-2016-ano-longoimpactos-direito-civil-contemporaneo>. Acesso em: 9 jan. 2018.

TARTUCE, Flávio. Direito civil. 10. ed. Rio de Janeiro: Forense, 2018. v. 4: Direito das coisas. TARTUCE, Flávio. Manual de direito civil. 8. ed. São Paulo: Método, 2018 (volume único). 
VENOSA, Sílvio de Salvo. Direito real de laje (criado pela Lei 13.465 de 2017). Disponível em: <http:// genjuridico.com.br/2017/11/08/direito-real-de-laje-lei-13-465-de-2017/>. Acesso em: 9 jan. 2018.

Recebido em: 13/04/2018

Aprovado em: 06/07/2018 